\title{
Who gains from credit granted between firms? Evidence from inter-corporate loan announcements made in China
}

\author{
He, Qing ; Lu, Liping ; Ongena, Steven
}

\begin{abstract}
Who gains from inter-corporate credit? To answer this question we measure the impact of the announcements of inter-corporate loans in China on the stock prices of the firms involved. We find that the average abnormal return for the issuers of inter-corporate loans is significantly negative, whereas it is positive for the receivers. Firms issuing inter-group loans may be perceived by investors to have run out of worthwhile projects to finance, although the loans may bring benefits to these firms through the high interest revenues involved. Firms receiving these inter-group loans are being certified as creditworthy borrowers, although the cost on these loans may be high. Issuance of intra-group loans on the other hand may signal the propping up of financially distressed subsidiaries and their resultant expropriation in the future and the firms granting and receiving such loans will be assessed accordingly. Subsequent investment and firm performance confirms these immediate valuations as overall accurate.
\end{abstract}

Posted at the Zurich Open Repository and Archive, University of Zurich

ZORA URL: https://doi.org/10.5167/uzh-175942

Conference or Workshop Item

Published Version

Originally published at:

He, Qing; Lu, Liping; Ongena, Steven (2019). Who gains from credit granted between firms? Evidence from inter-corporate loan announcements made in China. In: ASSA, Atlanta, 4 January 2019 - 6 January 2019, SSRN. 
Who Gains from Credit Granted between Firms?

Evidence from Inter-corporate Loan Announcements Made in China

\author{
Qing $\mathrm{He}$ \\ Renmin University of China \\ School of Finance \\ Zhongguancun Avenue 59, 100872 Beijing, China \\ Telephone: + 861082509260 \\ Email:qinghe@ruc.edu.cn
}

\author{
Liping Lu \\ VU University Amsterdam \\ Department of Finance
}

De Boelelaan 1105, 1081HV Amsterdam, The Netherlands

Telephone: +31 2059822 73, Fax: +31 205986020

E-mail: l.lu@vu.nl

\author{
Steven Ongena \\ University of Zurich, SFI and CEPR \\ Department of Banking and Finance \\ Plattenstrasse 32 (PLD F-02), CH-8032 Zurich, Switzerland \\ Telephone: + 41446343954 \\ Email: steven.ongena@bf.uzh.ch
}

This Draft: October 27, 2016 


\title{
Who Gains from Credit Granted between Firms? \\ Evidence from Inter-corporate Loan Announcements Made in China
}

\begin{abstract}
Who gains from inter-corporate credit? To answer this question we measure the impact of the announcements of inter-corporate loans in China on the stock prices of the firms involved. We find that the average abnormal return for the issuers of inter-corporate loans is significantly negative, whereas it is positive for the receivers. Firms issuing inter-group loans may be perceived by investors to have run out of worthwhile projects to finance, although the loans may bring benefits to these firms through the high interest revenues involved. Firms receiving these inter-group loans are being certified as creditworthy borrowers, although the cost on these loans may be high. Issuance of intra-group loans on the other hand may signal the propping up of financially distressed subsidiaries and their resultant expropriation in the future and the firms granting and receiving such loans will be assessed accordingly. Subsequent investment and firm performance confirms these immediate valuations as overall accurate.
\end{abstract}

Key words: Entrusted loan, inter-corporate loan, credit misallocation, certification

JEL classification: G30, G140, G210 


\section{Introduction}

Credit between firms plays a crucial role in many economies around the world (Almeida and Wolfenzon (2006)). Firms with limited access to intermediated funds rely heavily on financial inter-linkages with other firms (Gopalan, Nanda and Seru (2007)). This is particularly important in emerging economies, where the legal systems are weak. The absence of adequate legal enforcement makes it burdensome for firms to raise external financing (La Porta, Lopez-de-Silanes, Shleifer and Vishny (1997)), which may lead to credit rationing of formal finance by financial institutions. Inter-corporate lending may be less subject to credit rationing and therefore may support the high growth in emerging economies like China (Allen, Qian and Qian (2005)).

Despite their ubiquity, research on inter-corporate credit continues to be hampered by a lack of direct firm-to-firm level data. ${ }^{1}$ Thus, the inner workings of inter-corporate loans remain relatively unexplored. In this paper, we assemble a unique dataset to study the announcements of inter-corporate loans in the Chinese stock market during 2005-2012. ${ }^{2}$ Indeed, as small- and medium-sized enterprises (SMEs) may face substantial obstacles in obtaining bank credit (Poncet, Steingress and Vandenbussche (2010)), the Chinese government has allowed firms to obtain credit from other non-financial firms under the coordination of financial institutions.

\footnotetext{
${ }^{1}$ Garcia-Appendini and Montoriol-Garriga (2014) study U.S. firms' liquidity positions and Boissay and Gropp (2014) study defaults on payments to suppliers in France. Jacobson and Von Schedvin (2015) and Ellingsen, Jacobson and von Schedvin (2016) study a dataset that contains 52 million trade credit contracts issued by 51 suppliers over 9 years to about 199,000 unique customers in Sweden. See also Petersen and Rajan (1997), Love, Preve and Sarria-Allende (2007), and Burkart, Ellingsen and Giannetti (2011), among others.

${ }^{2}$ Relying on similar data sources Allen, Qian, $\mathrm{Tu}$ and $\mathrm{Yu}$ (2016) examine the role played by inter-corporate loans in shadow banking, while Chen, Ren and Zha (2016) study monetary policy transmission and small bank risk-taking through the brokering of this lending.
} 
These inter-corporate loans, also called "entrusted loans", are playing an increasingly important role in supplying credit to firms in China. ${ }^{3}$

The inter-corporate loans must be disclosed as a separate report of listed firms according to Chinese regulations. ${ }^{4}$ We can therefore observe the market reactions for inter-corporate loans, which is an important advantage over other studies. Analyzing stock market reactions to a corporate financing event can provide an immediate and comprehensive assessment for the valuation effect of such an event (Palmrose, Richardson and Scholz (2004)). We thereby break new ground in inter-corporate loan research by providing novel evidence on the reactions of the stock prices to inter-corporate loan announcements for both the issuing and the receiving firms. Furthermore, comprehensive information disclosed in the inter-corporate loan announcements enables us to glean specifics on the lending behavior involved, i.e., the relationship between lender and borrower, maturity, interest rate and collateral. To the best of our knowledge, there is no other published work that has studied - from a valuation perspective $-\mathrm{a}$ dataset with such comprehensive information on inter-corporate loans.

Inter-corporate loans can be categorized as inter- or intra-group loans, depending on whether the lender and borrower are affiliated with a different or the same business

\footnotetext{
${ }^{3}$ According to the China Securities Regulatory Commission (CSRC), an entrusted loan is a type of loan in which the lender (i.e., the principal) extends credit to the borrower (i.e., the trustee) at specified amount, maturity, interest rate, and usage of the loan. Banks and other financial institutions only act as account managers who earn commissions but bear no default risk. Instead, the lending firm bears all the default risk. Entrusted loans amounted to 2.55 trillion RMB in 2013 (i.e., about $\$ 400$ billion) and accounted for 14.7 percent of the total amount of financing in the country. Data source: People's Bank of China. The increase in entrusted loans in 2013 was equivalent to nearly 30 percent of bank loans, which almost doubled the portion of 2012. The Wall Street Journal featured reports on entrusted loans in China on December $8^{\text {th }}, 2011$, and May $1^{\text {st }}, 2014$.
}

${ }^{4}$ The CSRC requires all listed firms to announce major events which may influence their stock prices. 
group. When the firm grants a loan to another firm outside the business group, it is called an inter-group loan.

In economies with underdeveloped legal and financial systems, credit provided by financial institutions may be rationed. Firms face substantial obstacles in accessing formal finance, which thus rely heavily on alternative financing channels based on reputation and relationship. The alternative financing channels have advantages in alleviating information asymmetry and also in enhancing contract enforcement even in the absence of official contracts, and therefore can support the high growth rates observed in an emerging economy like China (Allen, Qian and Qian (2005)).

Inter-group lending, which in essence is a type of informal financing based on reputation and inter-firm relationships, may alleviate the credit rationing that exists in the formal financial sector. For example, one firm may have abundant cash, while the other may have promising investment opportunities in need of external financing. Inter-group lenders (e.g., suppliers) can often access insider information and have enforcement advantages over financial institutions, so inter-group loans could redistribute credit to more profitable firms in an efficient way. Thus, investors may react positively to the announcement of inter-group loans for the receiving firms. The issuance of inter-group loans, however, may covey a signal that the issuing firms are running out of worthy projects to finance, thus generating a negative market reaction on the stock prices of the issuing firms.

A firm may also lend to another firm within the same business group, which is then called an intra-group loan. In countries with underdeveloped external financial markets, firms often resort to the internal capital market of their business group, e.g., 
intra-group loans reallocate credit among member firms of business groups (Gopalan, Nanda and Seru (2007)).

There is a strand of literature on how credit is allocated in the internal capital markets. Stein (1997), among others, shows that an internal capital market can channel funds from firms with lower investment opportunities to others with higher profitable investment opportunities. Intra-group lenders often know more about the prospects of the borrowing firms than others such as banks. As an intra-group loan agreement is a type of fund flowing within the internal capital market, it may add value to both the receiving firms and the business group as a whole through a value-enhancing credit re-allocation among member firms. Furthermore, internal capital markets within business groups may provide a supporting mechanism for a financially distressed subsidiary to avoid default (Gopalan, Nanda and Seru (2007); Khanna and Yafeh (2005)).

However, Friedman, Johnson and Mitton (2003) show that credit re-allocation from financially healthy firms to financially distressed firms may constitute “corporate propping-up", involving potential expropriation in the future. According to this hypothesis, the intra-group loan may be granted to support affiliated firms in financial distress, while allowing corporate insiders to expropriate private benefits in good times. The issuance of intra-group loans may convey a signal of such propping-up for receiving firms, while it may also lead to a credit misallocation and an increased expropriation risk for the business group as a whole.

Finally, a distortion in the internal capital markets could enable corporate insiders to extract private benefits of control (Scharfstein and Stein (2000); Fan, Jin and Zheng (2014)), or to engage in tunneling and expropriating corporate resources 
(Claessens, Djankov and Lang (2000); Johnson, La Porta, Lopez-de-Silanes and Shleifer (2000); Bertrand, Mehta and Mullainathan (2002)). Thus, intra-group loans may be used by corporate insiders to expropriate outside investors. So the information content of intra-group loans depends on the efficiency of the resource re-allocation among member firms within business groups. As a result, the market reactions to intra-group loan announcements provide us a valuable benchmark to shed light on both the bright and dark side of internal capital markets.

To address the aforementioned issues, we examine market reactions to a sample of 719 hand-collected inter-corporate loans announced between 2005 and 2012. There are 155 announcements made by the borrowers and 564 announcements made by the lenders. Using a standard market model, we document a statistically significant two-day (day -1 to day 0) cumulative abnormal return (CAR) of 91 basis points (bps) on the stocks of the borrowing firms, and a CAR of $-42 \mathrm{bps}$ on the stocks of the lending firms.

When we divide our sample according to whether the lender and the borrower are affiliated with the same business group, we find that the receipt of both inter-group and intra-group loans generates significantly positive CARs. It is consistent with a certification effect by these non-financial corporate lenders of the borrowing firms, which is similar with the role of traditional banks. The positive announcement effects for the receipt of inter-group loans stands in pointed contrast to the findings in Bailey, Huang and Yang (2011) and Huang, Schwienbacher and Zhao (2012): They show that bank loan announcements in China result in negative abnormal returns for the borrowing firms. This may be due to banks' limited information and their well-known soft budget problem. Hence lenders of inter-group 
loans may have better private information and be less subject to social and political pressure to subsidize low-quality firms. Thus, receiving an inter-group loan in China may provide the type of certification similar to that associated with the receipt of a bank loan in the U.S. (James (1987)). However, a positive market reaction to the receipt of intra-group loans is consistent both with a certification of firms' quality, and with a credible commitment to prop up the receiving firms by their affiliated lenders.

To further distinguish the certification effect of intra-group loans, we disaggregate intra-group loans according to the relationship between the lenders and borrowers, i.e., we distinguish between subsidiaries, controlling shareholders, and firms with another relationship. We find that the issuance of intra-group loans is associated with significantly negative market reactions to the stocks of these affiliated lenders, which is mainly driven by intra-group loans to their subsidiaries. Intra-group loan to subsidiaries serves as a channel of credit re-allocation within business groups. ${ }^{5}$ If intra-group loans to subsidiaries certify a value-enhancing credit reallocation, it will exhibit a positive market reaction to the announcements of intra-group loan issuances. If intra-group loans are employed to support financially distressed subsidiaries, it will exhibit a negative market reaction to the announcements of intra-group loan issuances. We find that the empirical evidence is consistent with the latter hypothesis, i.e., intra-group loans are primarily employed to prop up financially distressed affiliates. Thus, issuing intra-group loans may indicate a misallocation of financial resources and lead to an increased default risk for the lending firm. Besides, we also find

\footnotetext{
${ }^{5}$ As a majority proportion of the issuance of intra-group loans goes to wholly owned subsidies of listed firms, it rules out the possibility of tunneling and expropriations. 
negative CARs for the issuance of inter-group loans, which signals a lack of worthy projects for the lending firms to finance.

Consistent with the above findings, intra-group loan agreements have larger loan amounts, lower interest rates, less collateral requirements and longer maturities than inter-group loan agreements. For example, firms can receive relatively more favorable credit terms (consistent with propping-up) from their affiliated lenders. In contrast, inter-group loans are more likely to be scrutinized by these non-financial corporate lenders. Furthermore, the CARs for both the receipt and issuance of inter-corporate loans are lower for loans with a higher interest rate spread. For the receipt of inter-corporate loans, it is consistent with the literature that favorable credit agreements can convey proprietary information to uninformed investors, which leads to a certification effect similarly as traditional bank loans. We also find that the revisions of inter-corporate loans are associated with higher market reactions, which are consistent with Lummer and McConnell (1989) and suggest a scrutiny by these non-financial corporate lenders. However, this relationship is muted when we restrict our sample to intra-group loans, which indicates a corporate propping-up instead of scrutiny by these affiliated lenders.

Furthermore, we investigate the factors affecting the likelihood of issuing or receiving inter-corporate loans. Firms with higher market to book ratio are less likely to issue inter-group loans, while the issuance of intra-group loans does not depend on this ratio. In contrast, firms with higher market to book ratio are more likely to receive inter-group loans, while the receipt of intra-group loans does not depend on it. Besides, state-controlled firms are more likely to issue and receive intra-group loans while this is not the case for inter-group loans, which suggests a potential credit 
misallocation by the state-owned enterprises. The issuance of inter-corporate loans generates lower CARs for loans to intra-group borrowers, and also for loans by lenders with higher market-to-book ratios and other accounts receivable (i.e., a proxy for inter-corporate loans outstanding). The receipt of inter-corporate loans is associated with lower CARs for loans from state-owned lenders and loans to non-state controlled borrowers. The results support the hypothesis that the issuance of inter-corporate loans signals a lack of worthy projects to finance in the lending firms, while the issuance of intra-group loans conveys a resource misallocation through propping-up and also potential financial distress in the borrowing affiliated firms.

Finally, we provide some suggesting evidence on the consequences of inter-corporate loans for the investment and performance for both issuers and receivers. We find that investment decreases significantly for firms with high market to book ratio that issue intra-group loans, while it is insignificant for firms with low market to book ratio that receive intra-group loans. In addition, the investment decreases for firms with high market to book ratio that issue inter-group loans, while it is insignificant for firms with low market to book ratio (and different from those with a high ratio). In contrast, investment increases for firms with a high market to book ratio that receive inter-group loans; although the latter effect is only marginal, there is a significant difference in investment between firms that receive intra-group versus inter-group loans. It confirms the signaling of a lack of investment opportunities in the issuing firms of inter-group loans in particular for firms with high market to book ratio, and a certification effect for the receiving firms of inter-group loans in particular for firms with high market to book ratio. Due to the propping-up concerns for intra-group loans, the firms receiving these loans do not increase their 
investment, which confirms the inefficiency of internal capital market in relocating credit within the business group.

The evidence also suggests that the profitability declines after the issuance of inter-corporate loans, in particular for firms with high growth opportunities. ${ }^{6}$ In contrast, we find no evidence that the profitability increases after the receipt of inter-corporate loans even for firms with high growth opportunities, which may be caused by an inefficient internal capital market for firms receiving intra-group loans, and a high interest burden for firms receiving inter-group loans. For the inter-group loans, the market reactions to the issuance announcements confirm a lack of worthwhile projects to finance in the issuing firms. For the intra-group loans, it confirms that lenders provide a propping-up for their affiliated firms at the expense of profit deterioration in the business group (the lenders). These results are broadly consistent with the "propping up" hypothesis for the internal capital markets. Intra-group loans enhance the valuation of the receiving firms, while endanger the valuation in the business group as a whole due to a resource misallocation through propping-up and increased default risk in the future.

Our study contributes to the literature in the following ways. First, we provide novel evidence on the market reactions to the announcements of inter-corporate loans, which contributes to the literature on information production by non-financial firms as creditors besides banks and non-bank financial institutions (Best and Zhang (1993); Billett, Flannery and Garfinkel (1995)). We show that the receipt of inter-corporate loans from non-financial firms is associated with positive market reactions, which

\footnotetext{
${ }^{6}$ Put differently, credit is misallocated when firms with high growth potential issue inter-corporate loans to others, while this is not so for firms with low growth potential. 
indicates a certification effect by these non-financial corporate lenders. Second, our study is also related with the literature on the internal capital market of business groups (Stein (1997); Gopalan, Nanda and Seru (2007)). Our results are consistent with the propping-up hypothesis for the business groups in emerging markets, which can enhance the valuation of the receiving firms. However, it may lead to a wealth loss in the business group as a whole, i.e., uninformed investors may perceive the use of internal capital markets as a signal of credit misallocation and increased default risks in the future. One unique contribution of our paper is to provide direct evidence on who gains from the credit granted between affiliated firms within business groups. The announcements of intra-group loans enable us to measure the wealth implications for credit reallocation among affiliated firms within business groups.

Finally, our findings can also shed light on the operation of informal credit market and provide direct evidence on the market reactions to the credit reallocation between business groups (Allen, Qian and Qian (2005)). We show that the extension of inter-corporate loans to unaffiliated firms (i.e., informal loans) is associated with a positive (negative) market reaction for the stock prices of receiving (issuing) firms, particularly for firms with higher growth opportunities. It suggests that issuing firms may run out of profitable projects to finance, and thus extend credit to other firms with higher growth opportunities. Uninformed investors may see these non-financial corporate lenders as more efficient in screening and monitoring the borrowers than traditional financial institutions. As a result, the credit reallocation among unaffiliated firms corrects the market distortions to some extent in the absence of a well-developed legal and financial system. 
The rest of this paper is organized as follows. Section 2 introduces the Chinese financial system. Section 3 sets out our hypotheses. Section 4 discusses the data and methodology. Section 5 provides summary statistics, determinants of loan issuance and receiving, and event studies of the issuance and receipt of inter-corporate loans. Section 6 links CARs to a set of loan, counter-party and firm-specific characteristics. Section 7 presents additional analyses on ex-post behaviors. Section 8 concludes.

\section{Institutional background}

\subsection{The financial system in China}

The formal financial sector is dominated by commercial banks in China (Allen, Qian and Qian (2005)) with a bank credit to GDP ratio (1.11) that is substantially higher than the average for the other countries in their sample (0.73). According to the National Bureau of Statistics of China, banks provided 51.4 percent of the total financing for Chinese firms in 2013. The banking system in China consists of a central bank, four large (national) state-owned banks, ${ }^{7}$ three policy banks, 12 (regional) joint-stock banks, hundreds of local banks (i.e., city/rural commercial banks, rural cooperative banks, and village and town banks), and city/rural credit cooperatives, etc. There are also hundreds of branches and offices of foreign banks which can conduct a limited set of commercial banking activities in China (Allen, Qian, Zhang and Zhao (2013)). Generally speaking, the four large state-owned banks dominate the banking market in China. In particular state-owned banks are mandated

\footnotetext{
${ }^{7}$ The four large stated-owned banks are Industrial and Commercial Bank of China, Bank of China, Construction Bank of China and Agriculture Bank of China.
} 
to pursue social benefits and stability, and their credit allocation is often based on some "noisy" information about the borrowers and not on commercial judgment (Bailey, Huang and Yang (2011)). Moreover, small and private firms have limited credit histories and collaterals, and will not receive government bailouts in case of defaults. Thus, banks favor lending to state-owned enterprises (SOEs) and large private firms, and discriminate against small and private firms in China (Firth, Lin and Wong (2008)).

The capital market, which mainly consists of a bond market and an equity market, is also relatively underdeveloped in China. The bond market remains under-developed until recent years, although corporate bonds were first issued in as early as 1986 . The market value of newly issued bonds in China was only 1.74 percent of GDP at the end of 2012, and corporate bond issuance accounts for just 11.19 percent of total bond issuance in China. In contrast, the newly established Shanghai Stock Exchange and Shenzhen Stock Exchange have enjoyed rapid expansion since their founding in 1990. As measured by total market capitalization, both of these stock exchanges ranked in the world's top ten at the end of 2011. However, the combined stock market capitalization is still quite small compared to the banking system. The market capitalization-to-GDP ratio was 52 percent in 2011 in China, which is much lower than the U.S. level. Despite its rapid growth, the stock market does not play a proper role in the country, where insider trading and speculation are prevalent (He and Rui (2014)). For example, the turnover rates on the Shanghai and Shenzhen Stock Exchanges are 178.5 and 344.3 percent, respectively, which is higher than most industrial countries and may indicate a widespread speculative trading (Allen, Qian, Zhang and Zhao (2013)). Moreover, the two stock exchanges were established so as to 
provide a new source of funding for SOEs and to reduce the financial burden of government bailouts. Up until 2005, about 80 percent of the (more than 1,100) listed enterprises were converted from SOEs in China, while a majority of listed firms are still owned or controlled by the government nowadays. The Chinese government's dual role as both regulators and shareholders reduces the effectiveness of the stock market in terms of resource allocation and risk diversification.

In sum, China is an emerging economy with an under-developed financial market with widespread state intervention and financial repression. Credit constrained borrowers especially small and medium-sized enterprises (SMEs) often resort to alternative financing channels as a major source for credit. Thus, the informal financing channels have become essential for the success of the corporations in the country, e.g. inter-corporate credit and internal capital markets, etc.

\subsection{Inter-corporate loans}

With the formal banking sector and capital markets primarily serving the SOEs and large private firms, SMEs face substantial obstacles in obtaining bank credit and thus often resort to alternative financing channels. Based on the reputation in the community and long-term relationship, informal financing may channel credit from state-owned and large private firms to SMEs thus supporting a fast growth of the Chinese economy (Bose (1998); Allen, Qian and Qian (2005)). A well-functioning informal financing system may fill in the gap due to their advantages in screening, monitoring, and enforcement versus traditional banks (Stiglitz (1990); Arnott and Stiglitz (1991)). 
One type of informal financing channel is the inter-corporate loan. Because direct lending activities among non-financial firms are prohibited in China before 2015, entrusted loans have moved in to facilitate the inter-corporate lending. ${ }^{8}$ Under financial regulations in China, non-financial firms can extend credit to other firms via entrusted loans in a process that is coordinated by banks and other financial institutions (banks hereafter). Lenders and borrowers can negotiate loan terms subject to certain financial regulations regarding for example loan amount, interest rate, maturity, and purpose, etc. ${ }^{9}$ Banks merely act as agents on behalf of the lenders and coordinate the loan procedures, e.g., the contract signing, loan withdrawals, and repayment, etc. However, banks do not bear any default risk for the entrusted loans, which are often treated as off-balance sheet items by banks. Appendix 1 gives a timeline for the related laws and regulations on entrusted loans (for what we will henceforth call inter-corporate loans).

The Chinese financial authorities imposed only a mild set of regulations on inter-corporate loans because of their beneficial effect on credit reallocation. The market for inter-corporate loans has witnessed a rapid expansion with the gradual liberalization of interest rates in China, and it has recently become a key source of financing. ${ }^{10}$ The interest rate ceiling for inter-corporate loans was abolished by the

${ }^{8}$ On March $8^{\text {th }}, 1993$, People's Bank of China (PBOC) promulgated administrative decrees on entrusted loans as regards financial trust companies. On April $5^{\text {th }}, 2001$, the PBOC released a regulation on entrusted loans, "Issues on Commercial Banks' Provision for Launching Entrusted Loans". For an overview of the evolution of financial regulation of entrusted loans in China, see Appendix 1 for a survey of the laws and regulations relating to entrusted loans.

9 "Lending General Provisions" by the People's Bank of China were formulated in accord with the "Law of the Commercial Banks" and other relevant laws on August $1^{\text {st }}, 1996$. Article 7 states that entrusted loans should comply with the "Lending General Provisions".

${ }^{10}$ The interest rates are under extensive regulation by the People's Bank of China (PBOC). PBOC set the benchmark interest rate along with a rate floor and rate ceiling. The interest rate is only allowed to vary within specified bounds. For example, PBOC set the benchmark lending rates, and the interest rate of 
People's Bank of China (PBOC) in October 2004, which enabled lenders to negotiate freely with borrowers on interest rates. Appendix 2 shows that the market share of inter-corporate loans has been growing rapidly, accounting for 15 percent of total financing in 2013 (the second largest financing source besides bank lending) and totaling 2.55 trillion RMB.

The rapid expansion of the inter-corporate loan business is a natural outcome of widespread financial repressions in China. On the one hand, there is favoritism toward SOEs and large private firms in accessing external finance. On the other hand, a substantial part of these firms are affiliated with a business group (Fisman and Wang (2010)), which can help them spin off bad assets and meet the IPO requirements by the China Securities Regulatory Commission (CSRC) (Fan, Jin and Zheng (2014)). These firms typically become much larger and more transparent after IPOs, and thus have a higher financial capacity and abundant credit, which can be channeled to unaffiliated SMEs in higher interest rates, ${ }^{11}$ or reallocated to other member firms in need of liquidity within the same business group. Thus, firms in need of credit could employ the abundant credit of other firms to finance their investment opportunities. Furthermore, firms with abundant credit can receive substantial interest revenues

commercial loans, including entrusted loans, must be between the floor and ceiling around the benchmark lending rate. China began its interest rate liberalization in 1996 by abolishing the ceiling on interbank lending rates. From 1998 to 2004, the ceiling for the lending rates gradually raised, and was abolished in October 2004 (except for credit cooperatives), while the floor remained unchanged at $90 \%$ of the benchmark lending rate. Recently, China took a further step toward a market-oriented rate by removing the lending rate floor on July $19^{\text {th }}, 2013$.

11 June $25^{\text {th }}, 2013$ (Reuters) - A deputy general manager in a state-owned steel firm says that the firm doesn't use the bank credit to expand production, as the average loss is 100 - 200 RMB per ton of steel sold. Entrusted loans are an attractive business option for his company. The firm borrows from banks at the benchmark lending rate (about six percent), and issues inter-corporate loans to borrowers at twice that rate. 
through extending inter-corporate loans with high interest rates, which may even constitute their major sources for profit. ${ }^{12}$

If the Chinese economy stays in a booming period, the transactions of entrusted loans seem to be safe and benefit both the lenders and borrowers. Nevertheless, the rapid expansion of entrusted loans has generated substantial concern about the credit risks involved in light of the gloomy prospects for the Chinese economy since the global financial crisis. ${ }^{13}$ Although there is only a limited number of defaults on these loans up until now, ${ }^{14}$ the risks of inter-corporate lending can increase the systemic risks of the financial system as such credit often ends up in the real estate market and investment platforms of local municipal governments, which have become a major concern for the financial stability in China.

Despite its increasing importance in reallocating credit among corporations, little is known about the inner working mechanism of these inter-corporate loan agreements and their impacts on corporate valuations. Employing a unique setting of mandatory disclosure requirement for inter-corporate loans by the CSRC, we try to fill in this gap by examining the market reactions to the announcements of issuance and receipt of inter-corporate loans, and their associated consequences on the corporate investment

\footnotetext{
${ }^{12}$ For example, the Zhejiang Longsheng Group Co., Ltd, a listed firm in Shanghai Stock Exchange (i.e. stock ID: 600352), says in its 2012 earnings report that it earns 93.4 million RMB from extending loans to other firms, which accounts for about half of its operating profits (189.2 million RMB).

${ }^{13}$ May 2, 2014 (Wall Street Journal)-the Zhejiang Longsheng Co. Ltd, a listed firm in Shanghai Stock Exchange (i.e. stock ID: 600352) reports that the company has earned 21.9 million RMB from the lending to other companies in 2013 with interest rates ranging from $23 \%$ to $25 \%$, which decreases by $77 \%$ from the level of 2012.

${ }^{14}$ For example, the Sunny Loan Top Co., Ltd, a listed firm in Shanghai Stock Exchange (i.e. stock ID: 600830 ), on $7^{\text {th }}$ Jun, 2014, reports 1.12 billion RMB entrusted loans outstanding at the end of 2013, among which 306 million is classified as doubtful and 5 million is classified as losses.
} 
and performance. Our paper therefore can cast light on the welfare implications of the inter-corporate loan as a type of informal financing channels.

\section{Hypotheses development}

Institutional lenders, such as banks, can enhance firm valuation by alleviating the information asymmetry of borrowers (Fama (1985); Boot (2000); Ongena and Smith (2000)). Approval of a bank loan is often perceived by uninformed investors as a good signal, especially for borrowers who suffer from severe information asymmetries. The positive excess returns on borrowers`stocks following bank loan announcements are widely documented in the literature. For example, James (1987) finds positive CARs of almost 200 basis points in a two-day period surrounding bank loan announcements. ${ }^{15}$ Billett, Flannery and Garfinkel (1995) show significant positive CARs on loans from non-bank financial institutions which are indistinguishable from bank loans. However, Lummer and McConnell (1989) show that the market reacts positively to loan renewals but not to new bank loan agreements.

The CARs on bank loan announcements are higher for borrowers who suffer more from information asymmetries (Best and Zhang (1993)), for example these could be the smaller borrowers (Maskara and Mullineaux (2011)). Certain types of lenders can also better alleviate the information asymmetry of bank loan agreements, as in the case of internationally syndicated loans in emerging economies (Harvey, Lins and Roper (2004)); for example also foreign or local banks, except for domestic

\footnotetext{
${ }^{15}$ Following work by Mikkelson and Partch (1986). James and Smith (2000) and Degryse, Kim and Ongena (2009) provide a critical review of the methodology and the extant empirical evidence.
} 
banks that are located far from their borrowers, may play that role (Ongena and Roscovan (2013)); or lenders with higher credit ratings (Billett, Flannery and Garfinkel (1995)).

However, the CARs on bank loan announcements change over time. Fields, Fraser, Berry and Byers (2006) for example show that CARs on bank loan announcements were positive in the 1970s and 1980s, whereas they disappeared afterwards except for smaller and poorly performing firms and periods of high credit risk spreads, a result also present in samples studied by Andre, Mathieu and Zhang (2001) and Ongena, Roscovan, Song and Werker (2014) for example. And Li and Ongena (2015) find that the CARs on bank loan announcements were positive during the global financial crisis although they were close to zero before that. They surmise that in a booming credit market the certification of corporate borrowers by banks started to play a lesser role, while during the crisis the banks' role was revitalized. Wang and Xia (2014) show that banks exert less effort in ex-ante screening and ex-post monitoring when they can securitize loans, which may also explain the changes in CARs on bank loans over the time.

There are also some studies investigating the loan announcement effect for lending institutions. For example, Megginson, Poulsen and Sinkey (1995) show that the announcements of syndicated loans to Latin American borrowers in the 1970s have negative CARs for the lending banks, while syndicated loans to U.S. borrowers in the 1980s have positive CARs.

However, bank credits are often granted based on non-commercial criteria and noisy insider information for prospective borrowers in emerging economies with an absence of adequate legal and financial systems. Under such a scenario, banks do not 
screen or monitor borrowers in a proper way, which results in inefficient lending and thus credit misallocation in the country. For example, Bailey, Huang and Yang (2011) show that the announcements of bank loans are associated with negative CARs on the borrower's stock, and obtaining bank loans predicts poorer subsequent performance of borrowers in China. Due to a malfunctioning of the formal credit market, an increasing literature has documented the existence and role played by informal credit market. Based on reputation and relationship, informal financial system can better screen and monitor the borrowers, and enforce loan repayment than banks and other financial institutions (Tsai (2002); Allen, Qian and Qian (2005)).

\subsection{Inter-group loans}

Inter-corporate loan, in particular those made among firms not affiliated with the same business group (inter-group loan), is an essential informal financing channel for firms that are shut out of formal credit market. Under an efficient informal credit market, inter-group loans should occur among firms with certain business relationships, e.g., customers, suppliers, or firms in the same industry, etc. Thus, the lending firms of inter-group loans may have an informational advantage over banks in screening and monitoring the borrowers. Furthermore, lenders may suffer a substantial loss in case of loan defaults, which incentivizes lending firms to acquire proprietary information about the borrowers ex ante, e.g., through long-term business relationship, supplier-customer relationship, or personal relationship with the CEOs, etc. As a result, obtaining an inter-group loan resembles traditional bank loans in industrial countries, which certifies the borrowers and conveys positive information to uninformed investors. Therefore, such an announcement should be good news for the 
receiving firms, which can lead to significantly positive excess returns on the stock of these receiving firms.

A typical non-financial firm should mainly engage in the production of goods and non-financial services. Thus, the issuance of inter-group loans may signal to uninformed investors that the issuing firms have run out of worthwhile projects to finance, even though the inter-group loans indeed improve the credit allocation in the issuing firms as in Hoff and Stiglitz (1997) and Bose (1998). ${ }^{16}$ Needless to say, lenders can benefit from inter-group loans via a substantially high interest rate than alternative investments (e.g., bank deposits). If the negative signaling effect of the growth opportunity dominates the positive credit reallocation effect, the announcements for the issuance of inter-group loans should end up in a negative market reaction to the stock prices of the receiving firms.

We also examine the real consequence of inter-group loans for the investment and performance of the receiving and issuing firms. Inter-group loans may provide alternative financing channels for high growing but credit constrained firms, i.e., relocate credit from firms with low growth opportunities to firms with high growth opportunities. Thus, the receiving firms may use the credit to increase their investment, while the issuing firms may reduce their investment due to a lack of worthwhile projects to finance. We expect that the investment after the announcements of inter-group loans should increase for the receiving firms while it should decrease for the issuing firms. However, the implication of inter-group loans on firm's performance is not clear. On the one hand, corporate performance may be

\footnotetext{
${ }^{16}$ Similarly, Yook (2003) show that the acquirers' stock prices suffer from negative market reactions to M\&A announcements, which may indicate that the acquirers have run out of other worthwhile projects to finance.
} 
improved (deteriorated) after the receipt (issuance) of inter-group loans, as the credit is channeled from low-productivity to high-productivity firms. On the other hand, interest revenues from inter-group loans could partially off-set the deteriorating performance of the issuing firms, but it may erode the profits of receiving firms due to cumbersome financial burdens. Although the interest rates of inter-group loans are often much higher than the basis lending rate, the interest revenues may not fully off-set the profit deterioration due to a lack of worthwhile projects to finance, thus ending up in a declining corporate performance in the issuing firms. Nonetheless, a high interest payment can outweigh the benefits of investing in profitable projects by the receiving firms, which may not lead to an improvement of corporate performance in the receiving firms.

\subsection{Intra-group loan}

Business groups often employ intra-group loans to reallocate credit among affiliated firms. In countries with under-developed legal and financial systems, firms are often affiliated with business groups to overcome financial constraints in raising external finance (Claessens, Fan and Lang (2006); Bae and Vidhan (2009)). Firms with good investment opportunities can obtain credit through the internal capital markets when the headquarters of the business group can allocate credit efficiently among group firms (Stein (1997)). Indeed, Buchuk, Larrain, Muñoz and Urzúa I. (2014) find that intra-group loans in Chile actually enhance firm investment and performance. Furthermore, Almeida, Kim and Kim (2015) show that internal capital markets of Korea business groups mitigate the negative effects on investment and performance during the Asian financial crisis. 
Business groups, however, may also come with a potential dark side, especially in emerging economies with weak investor protections. Ownership is often concentrated in business groups, and voting rights exceed cash flow rights through pyramid structures and cross-holdings by controlling shareholders in emerging economies (Claessens, Djankov and Lang (2000)). Thus, a majority of decision rights are often in the hands of corporate insiders, which may enable them to tunnel corporate resources for private benefits (Johnson, La Porta, Lopez-de-Silanes and Shleifer (2000)). For example, an extensive literature has identified tunneling activities in emerging economies with inadequate legal protections for investors (Bertrand, Mehta and Mullainathan (2002); Friedman, Johnson and Mitton (2003); Baek, Kang and Lee (2006); Jiang, Lee and Yue (2010)).

Certain ownership structures enable controlling shareholders to engage in tunneling, while it may also facilitate the propping-up within business group. Business groups often re-allocate funds to support financially distressed affiliates (Bae, Kang and Kim (2002); Mitton (2002); La Porta, Lopez-de-Silanes and Zamarripa (2003)), e.g. controlling shareholders transfer funds from healthier firms (or use private resources) to prevent distressed affiliated firms from bankruptcy. Therefore, controlling shareholders can maintain their private benefits of control, and expropriate corporate resources when these financially distressed affiliates turn profitable in the future (Friedman, Johnson and Mitton (2003)). As a result, controlling shareholders have strong incentives to engage in propping-up if their expected private benefits of control in the financially distressed firms outweigh the cost of corporate propping-up behaviors (Bae, Cheon and Kang (2008)). 
Intra-group loans issued by listed firms to controlling shareholders have been prohibited by the Chinese regulatory authorities ever since Oct 2005 (Jiang, Lee and Yue (2010); also see the "Notice on the Suggestion by the CSRC on Enhancing the Quality of Listed Firms"). Thus, most intra-group loans are issued by listed firms (high-cash-flow-right firms) to their wholly/partially owned subsidiaries (low-cash-flow-right firms), which suffer less from the tunneling concerns of inter-corporate loans in the country. ${ }^{17}$

Both the propping-up hypothesis and the efficient internal capital market hypothesis may hold for the credit relocation among affiliated firms of business groups. The efficient internal capital market proposes that firms with higher investment opportunities will receive more credit, while the propping-up hypothesis proposes that financially distressed firms will receive more credit. According to the efficient internal capital market hypothesis, controlling shareholders have proprietary information of affiliated firms, and thus can relocate financial resources from affiliated firms with low growth prospects to others with high growth prospects. The value-enhancing credit reallocation in the internal capital market can overcome the frictions in the external credit market, and increase the overall valuation of the business group. In contrast, corporate propping-up is mainly driven by controlling shareholders' incentive to support the financially distressed affiliates, and thus is less correlated with affiliated firms' growth prospect. Furthermore, the propping-up may increase the expropriation risk of the business group since controlling shareholders

\footnotetext{
${ }^{17}$ Tunneling within a business group often involves moving resources from low- to high-cash-flow right firms, as a controlling shareholder can increase its wealth if more resources are in firms where he has high cash flow rights (Johnson, La Porta, Lopez-de-Silanes and Shleifer (2000); Friedman, Johnson and Mitton (2003); La Porta, Lopez-de-Silanes and Zamarripa (2003); Baek, Kang and Lee (2006); Bae, 2008 \#3476\}).
} 
anticipate extracting more private benefits from these loan receiving firms in good times in the future.

The inter-corporate loans announced by affiliated firms provide us a unique setting to test these two competing hypothesis. If the internal capital market of a business group is efficient, the receipt of intra-group loans resembles traditional bank loans as the lenders have proprietary information of the borrowers. We expect that the announcements for the receipt of intra-group loans will lead to significantly positive excess returns on the stocks of the receiving firms. In particular, we expect the positive market reactions to be more pronounced for the receiving firms with higher investment opportunities. The issuance of intra-group loans, in particular those to subsidiaries, may lead to significantly positive excess returns on the stock of the issuing firms if the resource re-allocation increases the valuation of the whole business group. If the propping-up hypothesis holds, the receipt of intra-group loans will increase the valuation of affiliated firms as it conveys to uninformed investors a credible commitment of propping-up, which can benefit the minority shareholders of the receiving firms. However, the market reactions should be less correlated with borrowers' growth prospects as the propping-up is mainly driven by the incentive to support financially distressed affiliates. Furthermore, the propping-up may reveal to the uninformed investors an increased expropriation risk in the business group, i.e., controlling shareholders contribute resources in crisis times and expropriate corporate resources in good times. We expect that the announcements for the issuance of intra-group loans will lead to significantly negative excess returns on the stock of issuing firms, in particular for those loans extended to their subsidiaries. 
There are also fundamental differences of economic consequences from the two competing hypotheses. If the internal capital market is efficient, receiving firms employ the abundant credit of lending firms to increase their investments and improve corporate performance, while this value-enhancing credit re-allocation can also benefit the whole business group. Thus, if lenders extend loans to their subsidiaries, we propose an increase in both the investment and corporate performance in the receiving firms. In contrast, if the propping-up hypothesis holds, it may not lead to an increase in investment or performance after receiving intra-group loans. However, intra-group loans can still alleviate the financial burden of the receiving firms, thus may alleviate the deterioration in corporate performance. Moreover, corporate propping-up usually relocates funds from better performing firms to others with worse performance, thus conveying a signal of credit misallocation and potential tunneling risks when issuing intra-group loans to subsidiaries. Thus, we propose that firms issuing intra-group loans will have lower investment and consequently corporate performance deteriorates.

\section{Data and variables}

Our sample consists of non-financial firms traded on the Chinese stock market (both Shanghai and Shenzhen Stock Exchange). We firstly identify a sample of 1,024 announcements of inter-corporate loans during 2005-2012 from Resset (www.resset.cn), which is a widely used database for the Chinese stock market (Calomiris, Fisman and Wang (2010)). The CSRC requires all listed firms to 
announce major events which may influence their stock prices. ${ }^{18}$ We then crosscheck the announcements with the official documents of corporate announcements published on the websites designated by the CSRC, ${ }^{19}$ and the websites of the Shanghai and Shenzhen Stock Exchanges. Thus, we identify another 249 announcements of inter-corporate loans. So we reach a sample of 1,273 announcements of inter-corporate loans. Appendix 3 shows an example of an inter-corporate loan announcement record (translated by the authors).

We exclude all observations that coincide with other confounding corporate events (i.e., release of annual reports, announcement of seasonal offerings, dividend, law suits, etc.) within the $[-2,2]$ trading day window around the announcements date of an inter-corporate loan. We obtain a sample of 719 unaffected announcements of issuance and receipt of inter-corporate loans. Appendix 4 tabulates the total volume of inter-corporate loans by all listed firms on Shanghai Stock Exchange, which shows that our sample covers a quarter of the total volume of inter-corporate loans.

We record the announcement date, loan type (i.e., issuance / receipt), existing relationship between lender and borrower (i.e., inter-group and intra-group, where the

${ }^{18}$ According to Article 67 of Chapter 3 of the Securities Law of China (effective as of Oct 27, 2005), the term "major event" means: (1) A major change in the company's business guidelines or scope of business; (2) A decision made by the company concerning a major investment or major asset purchase; (3) Conclusion by the company of an important contract which may have an important effect on the company's assets, liabilities, rights, interests or business results; (4) Incurrence by the company of a major debt or default on an overdue major debt; (5) Incurrence by the company of a major deficit or incurrence of a major loss; (6) A major change in the external conditions of the company's production or business; (7) A change in the board of directors, no less than one-third of directors, supervisors or managers of the company; (8) A considerable change in the holdings of shareholders who hold no less than five percent of the company's shares; (9) A decision made by the company to reduce its capital, to merge, to divide, to dissolve, or to apply for bankruptcy; (10) Major litigation involving the company, or lawful cancellation by a court of a resolution adopted by the shareholders' general meeting or the board of directors; (11) Criminal cases involving the company, and the arrest of board of directors, supervisors or senior management staff; (12) Other events specified by the China Securities Regulatory Commission.

19 The official designated websites for corporate disclosures are www.cninfo.com.cn and www.cnstock.com. 
latter is further broken down into controlling shareholders, subsidiaries, and firms with other relationships, e.g., firms affiliated with the same business group but without equity ownership of each other), and ownership of the counter-party. In addition, we also record whether an inter-corporate loan is a new loan (issuance/receipt) or a loan revision. A new loan indicates that the borrower and lender do not have a prior inter-corporate loan between them, while a loan revision means there is an existing loan. The announcement files for inter-corporate loans enable us to identify loan terms such as the loan amount, interest rate, maturity, and collateral, and also the name of the financial institution involved, among other characteristics.

The inter-corporate loan announcements are matched with stock prices and a set of firm characteristics at the fiscal year-end before the announcement year. We collect financial information for non-listed firms from the announcement files of inter-corporate loans, and also from the survey of industrial firms by the National Bureau of Statistics of China. ${ }^{20}$ As a result, we can compile a set of firm characteristics which may be associated with the CARs on announcements of inter-corporate loans.

We include loan variables in the regression (loan size, interest rate, maturity, guarantee, and loan revision), as well as counter-party variables (intra-group and inter-group counter-party, counter-party industry, counter-party size, and state-owned counter-party). In addition, we include a set of firm variables: Size, age, market-to-book ratio, free cash flow, leverage, state-control, other accounts

\footnotetext{
${ }^{20}$ We use the dataset for industrial firms in China, which include all state-owned enterprises (SOEs) and all non-state owned firms with annual sales revenues above five million RMB, from 1998-2009.
} 
receivable, ${ }^{21}$ and other accounts payable. Finally, we include industry and year fixed effects in the regression. Variable definitions are listed in Table 1.

[Table 1 here]

\section{Results}

\subsection{Summary statistics}

We focus on 2005-2012 as our sample covers all announcements of inter-corporate loans in that period. Panel A of Table 2 shows the distribution of 719 "clean" announcements by type and year. A total of 564 announcements were made on the issuance of inter-corporate loans, and 155 announcements on their receipts. The number of announcements increases over the years, with a slight decrease in 2012, and there are more announcements of issuances than of receipts.

[Table 2 here]

Panel B of Table 2 shows the distribution of inter-corporate loan announcements by industry. A majority of the inter-corporate loans are in the manufacturing industry. The utilities industry ranks second in the number of issuance announcements of

${ }^{21}$ Accounting Standard for Business Enterprises of China (CAS) formulates the basic and specific standards for accounting information of financial reports. CAS, however, doesn't specify the accounting method for the book-keeping of entrusted loans. Entrusted loans can be reported in accounting entries of other accounting receivables, other liquid assets, held-to-maturity investment or disbursement of loans and advances in a firm's balance sheet. The interest revenues from issuing entrusted loans is reported in accounting entries of interest income, other business income, investment income or financial costs in a firm's income statement. For example, the 2009 annual report of the Sunny Loan Top (stock ID: 600830) discloses the firm's entrusted loans outstanding in the accounting entry of disbursement of loans and advances, while the revenue of entrusted loans appears in interest income. The 2011 annual report of China Coal Energy Company Ltd (stock ID: 601898) discloses the firm's entrusted loans in other accounts receivables, while it doesn't report the revenue from entrusted loans. 
inter-corporate loans, whereas the real estate industry ranks second for receipt announcements.

Panel A of Table 3 shows the characteristics of inter-corporate loans for issuance versus receipts as well as for intra-group versus inter-group loans. A majority of the announced inter-corporate loans are intra-group loans, on both issuance and receipts. Panel B of Table 3 shows a further decomposition of the intra-group loans into controlling shareholders, subsidiaries, and firms with other relationships. All issuances of intra-group loans go to the subsidiaries of listed firms except for four loans to the controlling shareholders, while a majority of the receipts of intra-group loans comes from the controlling shareholders. Table 3 also shows that issuance size is smaller than the receipt size for inter-corporate loans, the respective average loan sizes for issuance and receipt of inter-corporate loans being 185 and 300 (217 and 298 for intra-group loans) million RMB.

[Table 3 here]

Table 3 also shows that the maturity is 18 months on average for the issuance of intra-group loans and 12 months for the issuance of inter-group loans. The maturity for the receipt of intra-group loans is slightly longer than that for inter-group loans. In addition, the average interest rate spread is 14 versus 115 percent over the basis lending rate for the issuance of intra-group versus inter-group loans; and 4 versus 17 percent for the receipt of intra-group versus inter-group loans. Furthermore, the issuance of intra-group loans has a lower proportion of guarantees than inter-group loans (i.e., 13 versus 66 percent), which also applies to the receipt of intra-group versus inter-group loans (i.e., 9 versus 40 percent). 


\subsection{Determinants of issuing and receiving inter-corporate loans}

In order to identify factors that may affect the likelihood of issuing or receiving inter-corporate loans, we use the size-based matching method in Beasley (1996) and Bailey, Huang and Yang (2011). It allows us to identify a group of control firms with similar size and same industry. The dependent variable equals 1 for each firm-year in our sample, and 0 for a matching sample constructed for each firm-year from all firms that do not have any record on issuing or receiving inter-corporate loans in the sample period. Specifically, for each firm-year in our loan announcement sample, we identify all other firms from the same industry and choose the one with the closest value of total assets, as long as it is within the ten percent band of the sample firms' total assets. We then pool these matched firms with our sample firms, and run a regression of the likelihood of issuing or receiving inter-corporate loans on a set of firm characteristics.

Models (1)-(3) of Table 4 show that more mature firms are more likely to issue inter-group loans, while this is less likely the case for intra-group loans. In addition, firms with a higher market to book ratio are less likely to issue inter-group loans, while this ratio does not matter for the issuance of intra-group loans. Furthermore, firms with higher leverage are less likely to issue inter-group loans, while it does not matter for the issuance of intra-group loans. Besides, state-controlled firms are more likely to issue intra-group loans, while this is not the case for inter-group loans. And, firms with a CEO who is also a chairman of the board of directors are less likely to issue intra-group loans, which reflects the relative bargaining power in terms of credit re-allocation between the headquarter CEO and divisional CEO of a business group. 
[Table 4 here]

Models (4)-(6) of Table 4 show that more mature firms are less likely to receive inter-group loans. Also, firms with higher market to book ratio are more likely to receive inter-group loans, while market-to-book does not matter for the receipt of intra-group loans. In addition, firms with higher leverage are less likely to issue inter-group loans but more likely to receive inter-group loans. Furthermore, state-controlled firms are more likely to issue and receive intra-group loans, while not so for inter-group loans. Firms with higher profitability, however, are less likely to receive inter-group loans, which may reflect abundant cash flow in the firm thus a lower external credit demand.

\subsection{Market reactions to the issuance of inter-corporate loans}

A standard market model (as in Thompson (1985)) is used to estimate the benchmark returns and then to calculate the abnormal returns. In order to measure market returns, we use the equally-weighted market return for the Chinese stock market (A-shares) from the China Stock Market and Accounting Research (CSMAR) database. We define the announcement date as the event date (i.e., "day 0"). For each "clean" announcement of entrusted loans, we run a daily market model for the firms over the estimation window of $[-250,-21]$, and calculate abnormal returns in the event windows accordingly.

Since December 16, 1996, the Chinese government has imposed restrictions on the ceiling and floor of the daily stock price. Based on previous trading day's closing price, the ceiling and floor for the stock prices are set at ten percent for all stocks and 
five percent for stocks that are labeled as special treatment ("ST") status. ${ }^{22}$ Thus, the stock price may continue to react after the announcement day, which makes CAR[-1, $+1]$ an informative measure to capture a full market reaction besides the standard CAR $[-1,0]$. We also report results for various event windows (e.g., CAR[-2,+2]) to check the robustness of our findings.

The top panel of Table 5 shows the abnormal returns on the issuance of inter-corporate loans. The two-day cumulative abnormal return, i.e., CAR[-1,0], is -0.42 percent and statistically significant at the one percent level in a Student's t-test and significant at the one percent level in a Wilcoxon signed-rank test (i.e., the proportion of positive CARs is less than 50 percent). The results for $\mathrm{AR}[0]$ and CAR $[-1,1]$ are qualitatively similar. The upper panel of Appendix 5 shows the average abnormal returns for the issuance of inter-corporate loans in the $[-20,20]$ window, which exhibits a substantial drop in the average abnormal return on the event day.

[Table 5 here]

As multiple inter-corporate loan issuances may be announced on a single day, we split the sample into single-event versus multiple-events subsamples in order to get a cleaner effect. Thus, the middle panel of Table 5 shows that the CAR[-1,0] is -0.48 percent and statistically significant at the one percent level for the single-event subsample in both the t-test and Wilcoxon signed-rank test, and -0.17 percent and

\footnotetext{
${ }^{22}$ According to CSRC, a company can be downgraded to ST status if: (1) The firm records a net loss in two consecutive fiscal years; (2) The company is found to have committed financial fraud and, after taking remedial action, records a net loss in two consecutive fiscal years; (3) The company is found to have committed financial fraud, the company has failed to take remedial action within a specified period after being urged by the CSRC to do so, and the company has been temporarily delisted for two months; (4) The company has failed to issue its annual report or semi-annual report on the designated date and has been temporarily delisted for two months. Any company that fails to take steps to improve its situation after being designated ST will ultimately be delisted from the stock exchange.
} 
insignificant for the multiple-events subsample. We will focus on the single-event subsample for the issuance of inter-corporate loans hereafter.

Table 6 shows the issuance of inter-corporate loans by intra-group versus inter-group loans. The CAR[-1,0] for the issuance of intra-group loans is -0.62 percent and significant at the one percent level in both a t-test and a Wilcoxon singed-rank test, while it is -0.25 percent for inter-group loans and significant at one percent level in a Wilcoxon signed-rank test although statistically insignificant in a t-test. Furthermore, the results for $\mathrm{AR}[0]$ and $\mathrm{CAR}[-1,-1]$ are qualitatively similar.

In sum, the issuance of inter-corporate loans generates a negative market reaction, sending unfavorable signals to uninformed investors for both intra-group and inter-group loans. The issuance of inter-corporate loans may reveal a credit misallocation in a listed firm, e.g., a listed firm may run out of worthwhile projects to finance even when the inter-corporate loans may enhance the credit allocation.

[Table 6 here]

We also show the CARs separated into issuance of intra-group loans to controlling shareholders, subsidiaries, and borrowers with other relationships. Table 7 shows that the issuance of intra-group loans to subsidiaries constitutes a majority of the sample, while the set of loans issued to controlling shareholders contains only four observations due to government sanctions since 2006. Consistent with the tunneling of intra-group loans to controlling shareholders in Jiang, Lee and Yue (2010), the CAR[-1,0] equals -1.97 percent, though it is not statistically significant due to the limited number of observations. In addition, CAR $[-1,0]$ is -0.65 percent for the issuance of intra-group loans to subsidiaries, which is significant at the one percent 
level in both a t-test and a Wilcoxon signed-test. We do not find any significant CARs for the issuance of intra-group loans to borrowers with other relationships.

\section{[Table 7]}

Besides indicating a lack of worthwhile projects in the issuing firm, the issuance of intra-group loans to subsidiaries may also reveal financial distress in this subsidiary, which may spill over to the rest of the business group. Our results provide evidence consistent with the role of ICMs in supporting financially weaker firms in a business group (Gopalan, Nanda and Seru (2007); Almeida, Kim and Kim (2015)).

In sum, the negative CARs for the issuance of inter-group loans may reveal a credit misallocation to the uninformed investors, or rather a lack of worthwhile projects to finance for the issuing firms, even when such loans would improve credit allocation. The negative CARs for the issuance of inter-group loans indicate that high interest revenues from these loans do not fully off-set the deteriorating performance due to a lack of worthy projects in the issuing firms. Furthermore, the negative CARs for the issuance of intra-group loans to subsidiaries may reveal financial distress in the subsidiary which may spill over to the rest of the business group. Besides, the negative CARs for the issuance of intra-group loans to subsidiaries also suggest a propping-up by the listed firms, thus supporting the efficient internal capital market hypothesis.

\subsection{Market reactions to the receipt of inter-corporate loans}

Table 8 shows the abnormal returns for the receipt of inter-corporate loans. The $\mathrm{CAR}[-1,0]$ is 0.91 percent and statistically significant at the one percent level in a 
t-test, and also at the ten percent level in a Wilcoxon signed-rank test. In addition, CAR $[-1,0]$ is 1.09 percent and statistically significant at the one percent level in a t-test and at the five percent level for the Wilcoxon signed-rank test for the receipt of inter-corporate loans in the single-event subsample, and -0.59 percent in the multiple-events subsample (but not significant). Similarly, we will focus on the single-event subsample for the receipt of inter-corporate loans hereafter. The results are qualitatively similar for other event windows, such as AR[0], CAR[-1,1], and CAR[-2,2]. The lower panel of Appendix 5 shows a substantial jump upward in the average abnormal return on the event day of the receipt of inter-corporate loans. In sum, the receipt of inter-corporate loans has a certification effect for the borrowing firms in China, as do traditional bank loans in the U.S.

[Table 8 here]

We further tabulate the receipts of inter-corporate loans by intra-group versus inter-group loans. The top panel of Table 9 shows that the CAR $[-1,0]$ for the receipt of intra-group loans is 1.06 percent and statistically significant at the one percent level in a t-test and also at the five percent level in a Wilcoxon signed-rank test. The CAR[-1,0] is 1.33 percent for inter-group loans (but not statistically significant). The results are qualitatively similar for other event windows, e.g., $\mathrm{AR}[0], \mathrm{CAR}[-1,1]$, and $\mathrm{CAR}[-2,2]$. We find that the intra-group loans also have a certification effect for the borrowing firms, which may be due to their proprietary information due to affiliation with the same business group.

[Table 9 here] 
We also tabulate the receipts of intra-group loans by those from controlling shareholders, subsidiaries, and lenders with other relationships. Table 10 shows that intra-group loans from controlling shareholders constitute a majority of the sample. The CAR[-1,0] is 1.42 percent for the receipt of intra-group loans from controlling shareholders and is statistically significant at the one percent level in both a t-test and a Wilcoxon signed-rank test. The positive CARs of the receipts of intra-group loans from controlling shareholders also suggest corporate propping-up activities, which may benefit the loan receiving firms but bring a wealth loss to the whole business group (i.e., inefficient internal capital market hypothesis). Furthermore, the receipt of intra-group loans from lenders with other relationship has a CAR[-1,0] of 0.37 percent (but not statistically significant). However, we do not find any clear evidence for the receipt of intra-group loans from subsidiaries, likely due to the limited number of observations.

[Table 10 here]

In sum, the receipt of inter-group loans may provide certification for the borrowing firms as traditional bank loans. However, the receipt of loans from controlling shareholders can provide a creditable commitment of corporate propping-up, which also leads to positive CARs to the stock of receiving firms. Our results are consistent with the literature on corporate propping-up by controlling shareholders in emerging markets (Friedman, Johnson and Mitton (2003); Jian and Wong (2010); Peng, Wei and Yang (2011)). 


\section{CARs and loan, counter-party and firm characteristics}

We link the CARs with loan, counter-party, and firm level variables. Firstly, we include loan variables, i.e., loan size, spread of the interest rate over basis lending rate, maturity, guarantee status (whether a loan is collateralized or guaranteed by third-parties), loan revision (whether a loan announcement relates to a revision of loan terms such as extension of maturities). We also include a set of counter-party variables, i.e., intra-group versus inter-group loans, whether the counter-party and the listed firm are in the same industry, counter-party size, and whether the counter-party is state-owned, etc. Finally, we include a set of firm level variables, i.e., firm size, age, market-to-book ratio, free cash flow, leverage, state control, other accounts receivable, and other accounts payable, etc. The balance of the issuance of inter-corporate loans is typically recorded in other accounts receivable, and while their receipt is often recorded in other accounts payable. Jiang, Lee and Yue (2010) show that other accounts receivable captures the tunneling activities of controlling shareholders. Because this channel has been closed since 2006, only four inter-corporate loans were issued to controlling shareholders. We include other accounts receivable and payable to measure the balance of inter-corporate loans outstanding at the fiscal year-end before these announcements.

Appendix 6 shows summary statistics for the variables in the regression. Firms announcing the issuances of inter-corporate loans are more likely to be larger, more mature, state-controlled, and to have lower market to book ratio, lower leverage ratio, and lower other accounts receivable (i.e., lower inter-corporate loan issuances in the past) than those without any inter-corporate loan announcement. However, firms issuing inter-corporate loans are more likely to have lower free cash flow, which 
shows that the issuing firms may not simply relocate abundant cash for higher investment returns, e.g., rescuing group firms even though the list firm does not have abundant cash. In contrast, firms announcing the receipt of inter-corporate loans are more likely to be larger, more mature, state-controlled, and have higher leverage ratio, and higher other accounts payable (i.e., higher inter-corporate loans receipts in the past).

Table 11 shows the regressions of CAR[-1,0] for the issuance and receipt of inter-corporate loans on the loan, counter-party and firm characteristics. Models (1) to (4) give the estimates for the issuance, and Models (5) to (8) for the receipt of inter-corporate loans. Model (1) of Table 11 shows that the CARs on the issuance of inter-corporate loans are negatively associated with the interest rate spread over the basis lending rate. Model (2) shows that CARs on the issuance of inter-corporate loans are lower for intra-group loans, which may be due to a signaling effect as to the financial distress of a group firm, and inefficient internal capital market through corporate propping-up. Specifically, intra-group loans to subsidiaries at a higher interest rate may reveal a high default risk in these subsidiaries, which could spill over to the rest of the business group.

\section{[Table 11 here]}

Model (3) of Table 11 shows that more mature firms in the stock market generate higher CARs on the issuance of inter-corporate loans, as uninformed investors may already know their low growth potential, and also be less concerned about default risks for the borrowing subsidiaries. Furthermore, Model (4) shows that firms with higher market-to-book ratios have lower CARs due to more severe credit misallocation in the fast-growing issuing firms. In other words, an issuance of an 
inter-corporate loan by a firm with higher growth prospects may provide more valuable proprietary information to the uninformed investors on a lack of worthwhile projects to finance in the issuing firm. Finally, the CARs are lower for issuers with higher other accounts receivable, i.e., the issuing firms already have substantial issuances of inter-corporate loans outstanding, which may further confirm credit misallocation in the issuing firm and financial distress in a group firm, and further aggravates the corporate propping-up concerns.

Model (5) of Table 11 shows the regression results for CARs on the receipt of inter-corporate loans on loan variables, with no variables being statistically significant. The CARs are lower for loans with higher interest rate spreads, and these are significant at the ten percent level when we control for counter-party variables in Model (6), and further the firm characteristics in Model (8). A wider interest rate spread shows a higher default risk in the borrowing firm, which may attenuate the certification effect for these non-financial corporate lenders. However, there is no difference between intra-group and inter-group lenders for the market reactions to the receipt of inter-corporate loans.

State-owned lenders are associated with lower CARs in Model (8), which is significant at the five percent level and shows that these state-owned lenders are less credit-worthy in terms of certification for the borrowing firms. In contrast, state controlled firms are associated with higher CARs when receiving inter-corporate loans. State controlled firms are often worse in terms of performance, and inter-corporate loans may have a larger certification effect for such borrowing firms. Other accounts payable, however, is insignificant though the sign is positive in Model (8) of Table 11. Our results are generally consistent with the bank loan announcement 
literature in that certification is more effective if given by more credit-worthy lenders (Billett, Flannery and Garfinkel (1995)), and also more effective for poorly performing borrowers (Fields, Fraser, Berry and Byers (2006)).

In sum, we find that the CARs on issuance and receipt of inter-corporate loans are associated with various loan, counter-party, and (loan-announcing) firm variables. On the one hand, the issuance of inter-corporate loans generates lower CARs for loans with wider interest rate spreads, for intra-group loans, for firms with a higher market-to-book ratios, and with higher other accounts receivable (i.e., higher issuances of inter-corporate loans outstanding). On the other hand, the receipt of inter-corporate loans generates lower CARs for the loans with a higher interest rate spread, loans from state-owned lenders, and loans to non-state controlled borrowers. The results support the hypothesis that the issuance of inter-corporate loans signals to uninformed investors a lack of worthwhile projects to finance in the issuing firms, while the issuance of intra-group loans conveys additional information of financial distress in a group firm, and also the inefficient internal capital market in terms of corporate propping-up.

\section{Corporate investment and performance in the long-run}

In addition, we examine the economic consequence (changes in investment and performance) of inter-corporate loans for both issuing and receiving firms as it reflects how the credit is allocated across firms ex post. On the one hand, if the positive market reaction to the receipt of inter-group loans indicates a certification, 
this capital relocation can alleviate financial restrictions and enable the receiving firms to invest more than the issuing firms. On the other hand, the issuance of intra-group loans conveys additional information about the inefficient internal capital market in terms of corporate propping-up. The investment of the receiving firms $e x$ post the intra-group loans should be irreverent with their investment opportunities.

We explore the changes of capital expenditures scaled by the total assets in the years around the loan announcements for both the issuing and receiving firms. Table 12 shows the changes of capital expenditures in the years around the issuance of inter-corporate loans scaled by the total asset in the year before the loan announcements. We find that the capital expenditure decreases for the issuing firms with high market to book ratio while insignificant for the receiving firms (both the intra-group and inter-group loans). In particular, the difference between firms issuing inter-group loans with high versus low market to book ratio is significant at the one percent level. However, we do not find any significant difference between firms issuing intra-group loans and with high versus low market to book ratio. Put differently, firms issuing inter-corporate loans indeed invest less ex post especially for firms with high market to book ratio, which confirms a lack of investment opportunities in the issuers. The intra-group loans, however, may be used as a channel for corporate propping up, which endangers the investment behaviors of both the issuers and receivers of intra-group loans.

[Table 12 here]

The changes in the performance ex post the inter-corporate loans can also cast light on their long-term wealth effect. We examine firms' accounting performance 
after the inter-corporate loan announcements. If the issuance of inter-corporate loans reveals credit misallocation in the issuing firms (i.e., inter-group loan) or financial distress in a subsidiary (i.e., intra-group loan), we would expect the accounting performance to turn worse ex post. In contrast, if the receipt of inter-corporate loans provides certification for the receiving firms (inter-group loan) or corporate propping-up (intra-group loan, i.e. less financial burdens), we would expect a higher accounting performance ex post. Table 13 shows the return on assets (ROA) in the years before and after inter-corporate loan announcements.

[Table 13 here]

In addition, we find that ROA decreases significantly from one year before to two years after inter-corporate loan announcements for firms issuing both intra-group and inter-group loans, and with relatively higher market to book ratio but not for firms with a lower market to book ratio. A t-test between the two groups of firms shows that ROA decreases more for firms with high market to book ratio, which are significant at the ten and five percent level for intra-group and inter-group loans respectively. Firms with higher growth potential indeed perform worse after the issuance of inter-corporate loans, which is consistent with a revelation for a lack of worthwhile projects to finance in the issuing firms, and a misallocation of credit from high-growing firms to others. Firms with lower growth potential, however, can benefit from the high interest revenue of the inter-group loans, which can alleviate the performance deterioration. Besides, the issuance of intra-group loans may also reveal the corporate propping up and the default risks within the business group. The results are qualitatively similar when we look at the change from one year before and one year afterwards, and from the announcement year to two years afterwards. 
We find that ROA increases (though insignificant) from the announcement year to two years after the receipt of (i.e., low interest rate) intra-group loans in Table 13, which reduces the financial burdens of the receiving firms. In contrast, the performance of the firms receiving inter-group loans deteriorates (though insignificant) in Table 13, which may be caused by the higher interest burdens of these loans. However, there is no significant difference between the receiving firms with high versus low market to book ratio, or intra-group versus inter-group loans.

\section{Conclusion}

The granting of entrusted loans in China provides us with a unique setting to assess the valuation effects of inter-corporate lending and borrowing. We find that investors react negatively to the issuance of inter-corporate loans but positively to their receipt. The issuing of inter-corporate loans may indicate credit misallocation to uninformed investors, i.e., the issuing firms run out of worthy projects to finance. Furthermore, the issuance of inter-corporate loans to subsidiaries may reveal financial distress in that subsidiary, which may eventually spill over to the rest of the business group.

On the other hand, the receipt of intra-group loans, especially those from controlling shareholders, provides certification for the borrowing firms. In contrast to bank loan announcements, which often provoke negative market reactions (Bailey, Huang and Yang (2011)), non-financial corporate lenders in China can convey proprietary information to the uninformed investors. 
We also confirm our results by linking the CARs to loan, counter-party, and firm level variables. The issuance of inter-corporate loans generate lower CARs for the intra-group loans, for loans with higher interest rate spreads, and for loans granted by young issuers, with higher market-to-book ratios and larger outstanding issuances of inter-corporate loans. In contrast, the receipt of inter-corporate loans generates lower CARs on loans with higher interest rate spreads, on loans from state-owned lenders, and on loans to non-state-controlled borrowers. Our results shed light on inter-corporate loans as signaling devices for credit misallocation by issuing firms, and for financial distress in a borrowing subsidiary, which can spill over to the rest of the business group.

We further examine the ex post consequences on the investment and performance by these inter-corporate loans. On the one hand, firms with high growth potential that issue inter-corporate loans cut down their corporate investment, while the receiving firms of intra-group loans do not increase their corporate investment, which suggests a credit misallocation in the internal capital market within the business group. On the other hand, firms with higher growth potential that issue inter-corporate loans have a worse performance, which confirms a lack of worthwhile projects to finance. Firms with lower growth potential that issue inter-group loans, however, can alleviate the deterioration of the performance through the high interest revenue from these loans. Firms receiving intra-group / inter-group loans do not have better performance, which may be caused by the corporate propping-up for the former and a high interest burden by these loans for the latter.

Although inter-corporate loans play an increasingly important role in China, we still know little about the welfare gains from these loans. Because inter-corporate 
loans rarely arise between listed firms, we cannot calculate the net gains from such loans. Further research on the net gains from inter-corporate loans would provide more insight on whether or not such loans should be encouraged. 


\section{References}

Allen, F., J. Qian, and M. Qian, 2005, "Law, Finance and Economic Growth in China," Journal of Financial Economics 77, 57-116.

Allen, F., J. Qian, C. Zhang, and M. Zhao, 2013, "China's Financial System: Opportunities and Challenges," in J. Fan and R. Morck, eds, Capitalizing China, University of Chicago Press, Chicago IL.

Allen, F., Y. Qian, G. Tu, and F. Yu, 2016, Entrusted Loans: A Close Look at China's Shadow Banking System, Imperial College, London, Mimeo.

Almeida, H., C.-S. Kim, and H. B. Kim, 2015, "Internal Capital Markets in Business Groups: Evidence from the Asian Financial Crisis," Journal of Finance 70, 2539-2586.

Almeida, H. V., and D. Wolfenzon, 2006, "A Theory of Pyramidal Ownership and Family Business Groups," Journal of Finance 61, 2637-2680.

Andre, P., R. Mathieu, and P. Zhang, 2001, "A Note On: Capital Adequacy and the Information Content of Term Loans and Lines of Credit," Journal of Banking and Finance 25, 431-444.

Arnott, R., and J. E. Stiglitz, 1991, "Moral Hazard and Nonmarket Institutions: Dysfunctional Crowding Out of Peer Monitoring?," American Economic Review 81, 179-190.

Bae, G. S., Y. S. Cheon, and J.-K. Kang, 2008, "Intragroup Propping: Evidence from the Stock-Price Effects of Earnings Announcements by Korean Business Groups," Review of Financial Studies 21, 2015-2060.

Bae, K.-H., J.-K. Kang, and J.-M. Kim, 2002, "Tunneling or Value Added? Evidence from Mergers by Korean Business Groups," Journal of Finance 57, 2695-2740.

Bae, K.-H., and G. K. Vidhan, 2009, "Creditor Rights, Enforcement and Bank Loans," Journal of Finance 64, 823-860.

Baek, J.-S., J.-K. Kang, and I. Lee, 2006, "Business Groups and Tunneling: Evidence from Private Securities Offerings by Korean Chaebols," Journal of Finance 61, 2415-2449.

Bailey, W., W. Huang, and Z. Yang, 2011, "Bank Loans with Chinese Characteristics: Some Evidence on Inside Debt in a State-Controlled Banking System," Journal of Financial and Quantitative Analysis 46, 1795-1830.

Beasley, M. S., 1996, "An Empirical Analysis of the Relation between the Board of Director Composition and Financial Statement Fraud," Accounting Review 71, 443-465.

Bertrand, M., P. Mehta, and S. Mullainathan, 2002, "Ferreting out Tunneling: An Application to Indian Business Groups," Quarterly Journal of Economics 117, 121-148.

Best, R., and H. Zhang, 1993, "Alternative Information Sources and the Information Content of Bank Loans," Journal of Finance 48, 1507-1522. 
Billett, M. T., M. J. Flannery, and J. A. Garfinkel, 1995, "The Effect of Lender Identity on a Borrowing Firm's Equity Return," Journal of Finance 50, 699-718.

Boissay, F., and R. Gropp, 2014, "Payment Defaults and Interfirm Liquidity Provision," Review of Finance Forthcoming.

Boot, A. W. A., 2000, "Relationship Banking: What Do We Know?," Journal of Financial Intermediation 9, 3-25.

Bose, P., 1998, "Formal-Informal Sector Interaction in Rural Credit Markets," Journal of Development Economics 56, 265-280.

Buchuk, D., B. Larrain, F. Muñoz, and F. Urzúa I., 2014, "The Internal Capital Markets of Business Groups: Evidence from Intra-Group Loans," Journal of Financial Economics Forthcoming.

Burkart, M., T. Ellingsen, and M. Giannetti, 2011, "What You Sell Is What You Lend? Explaining Trade Credit Contracts," Review of Financial Studies 24, 1261-1298.

Calomiris, C. W., R. Fisman, and Y. Wang, 2010, "Profiting from Government Stakes in a Command Economy: Evidence from Chinese Asset Sales," Journal of Financial Economics 96, 399-412.

Chen, K., J. Ren, and T. Zha, 2016, What We Learn from China's Rising Shadow Banking: Exploring the Nexus of Monetary Tightening and Banks' Role in Entrusted Lending, National Bureau of Economic Research, Cambridge MA, Working Paper.

Claessens, S., S. D. Djankov, and L. H. P. Lang, 2000, "The Separation of Ownership and Control in East Asian Corporations," Journal of Financial Economics 58, 81-112.

Claessens, S., J. Fan, and L. Lang, 2006, "The Benefits and Costs of Group Affiliation: Evidence from East Asia," Emerging Markets Review 7, 1-26.

Degryse, H., M. Kim, and S. Ongena, 2009, Microeconometrics of Banking: Methods, Applications and Results, Oxford University Press.

Ellingsen, T., T. Jacobson, and E. von Schedvin, 2016, Inter-Firm Lending: Contract-Level Evidence Contradicts Current Theories, Riksbanken, Stockholm, Working Paper.

Fama, E. F., 1985, "What's Different about Banks?," Journal of Monetary Economics 15, 5-29.

Fan, J. P. H., L. Jin, and G. Zheng, 2014, "Revisiting the Bright and Dark Sides of Capital Flows in Business Groups," Journal of Business Ethics 1-20.

Fields, L. P., D. R. Fraser, T. L. Berry, and S. Byers, 2006, "Do Bank Loan Relationships Still Matter?," Journal of Money, Credit, and Banking 38, 1195-1209.

Firth, M., C. Lin, and S. M. L. Wong, 2008, "Leverage and Investment under a State-owned Bank Lending Environment: Evidence from China," Journal of Corporate Finance 14, 642-653.

Fisman, R., and Y. Wang, 2010, "Trading Favors within Chinese Business Groups," American Economic Review 100, 429-33.

Friedman, E., S. Johnson, and T. Mitton, 2003, "Propping and Tunneling," Journal of Comparative Economics 31, 732-750. 
Garcia-Appendini, E., and J. Montoriol-Garriga, 2014, "Firms as Liquidity Providers: Evidence from the 2007-2008 Financial Crisis," Journal of Financial Economics 109, 272-291.

Gopalan, R., V. Nanda, and A. Seru, 2007, "Affiliated Firms and Financial Support: Evidence from Indian Business Groups," Journal of Financial Economics 86, 759-795.

Harvey, C. R., K. V. Lins, and A. H. Roper, 2004, "The Effect of Capital Structure When Expected Agency Costs Are Extreme," Journal of Financial Economics 74, $3-30$.

He, Q., and O. M. Rui, 2014, "Ownership Structure and Insider Trading: Evidence from China," Journal of Business Ethics 1-22.

Hoff, K., and J. E. Stiglitz, 1997, "Moneylenders and Bankers: Price-increasing Subsidies in a Monopolistically Competitive Market," Journal of Development Economics 52, 429-462.

Huang, W., A. Schwienbacher, and S. Zhao, 2012, "When Bank Loans are Bad News: Evidence from Market Reactions to Loan Announcements under the Risk of Expropriation," Journal of International Financial Markets, Institutions and Money 22, 233-252.

Jacobson, T., and E. Von Schedvin, 2015, "Trade Credit and the Propagation of Corporate Failure: An Empirical Analysis," Econometrica 83, 1315-1371.

James, C., and D. C. Smith, 2000, "Are Banks Still Special? New Evidence on Their Role in the Corporate Capital Raising Process," Bank of America - Journal of Applied Corporate Finance 13, 52-63.

James, C. M., 1987, "Some Evidence on the Uniqueness of Bank Loans," Journal of Financial Economics 19, 217-235.

Jian, M., and T. J. Wong, 2010, "Propping through Related Party Transactions," Review of Accounting Studies 15, 70-105.

Jiang, G., C. M. C. Lee, and H. Yue, 2010, "Tunneling through Intercorporate Loans: The China Experience," Journal of Financial Economics 98, 1-20.

Johnson, S., R. La Porta, F. Lopez-de-Silanes, and A. Shleifer, 2000, "Tunneling," American Economic Review 90, 22-27.

Khanna, T., and Y. Yafeh, 2005, "Business Groups and Risk Sharing around the World," Journal of Business 78, 301-340.

La Porta, R., F. Lopez-de-Silanes, A. Shleifer, and R. W. Vishny, 1997, "Legal Determinants of External Finance," Journal of Finance 22, 1131-1150.

La Porta, R., F. Lopez-de-Silanes, and G. Zamarripa, 2003, "Related Lending," Quarterly Journal of Economics 128, 231-268.

Li, C., and S. Ongena, 2015, "Bank Loan Announcements and Borrower Stock Returns Before and During the Recent Financial Crisis," Journal of Financial Stability 21, 1-12.

Love, I., L. A. Preve, and V. Sarria-Allende, 2007, "Trade Credit and Bank Credit: Evidence from Recent Financial Crises," Journal of Financial Economics 83, 453-469. 
Lummer, S. L., and J. J. McConnell, 1989, "Further Evidence on the Bank Lending Process and the Capital Market Response to Bank Loan Agreements," Journal of Financial Economics 25, 99-122.

Maskara, P. K., and D. J. Mullineaux, 2011, "Information Asymmetry and Self-selection Bias in Bank Loan Announcement Studies," Journal of Financial Economics 101, 684-694.

Megginson, W. L., A. B. Poulsen, and J. F. J. Sinkey, 1995, "Syndicated Loan Announcements and the Market Value of the Banking Firm," Journal of Money, Credit and Banking 27, 457-475.

Mikkelson, W. H., and M. M. Partch, 1986, "Valuation Effects of Security Offerings and the Issuance Process," Journal of Financial Economics 15, 31-60.

Mitton, T., 2002, "A Cross-Firm Analysis of the Impact of Corporate Governance on the East Asian Financial Crisis," Journal of Financial Economics 64, 215-241.

Ongena, S., and V. Roscovan, 2013, "Bank Loan Announcements and Borrower Stock Returns: Does Bank Origin Matter?," International Review of Finance 13, 137-159.

Ongena, S., V. Roscovan, W.-L. Song, and B. Werker, 2014, "Banks and Bonds: The Impact of Bank Loan Announcements on Bond and Equity prices," Journal of Financial Management, Markets and Institutions 2, 3-28.

Ongena, S., and D. C. Smith, 2000, "Bank Relationships: a Review," in P. Harker and S. A. Zenios, eds, The Performance of Financial Institutions, Cambridge University Press, London.

Palmrose, Z.-V., V. J. Richardson, and S. Scholz, 2004, "Determinants of Market Reactions to Restatement Announcements," Journal of Accounting and Economics 37, 59-89.

Peng, W. Q., K. C. J. Wei, and Z. Yang, 2011, "Tunneling or Propping: Evidence from Connected Transactions in China," Journal of Corporate Finance 17, 306-325.

Petersen, M. A., and R. G. Rajan, 1997, "Trade Credit: Theories and Evidence," Review of Financial Studies 10, 661-691.

Poncet, S., W. Steingress, and H. Vandenbussche, 2010, "Financial Constraints in China: Firm-Level Evidence," China Economic Review 21, 411-422.

Scharfstein, D. S., and J. C. Stein, 2000, "The Dark Side of Internal Capital Markets: Divisional Rent-Seeking and Inefficient Investment," Journal of Finance 55, 2537-2564.

Stein, J. C., 1997, "Internal Capital Markets and the Competition for Corporate Resources," Journal of Finance 52, 111-133.

Stiglitz, J. E., 1990, "Peer Monitoring and Credit Markets," World Bank Economic Review 4, 351-366.

Thompson, R., 1985, "Conditioning the Return-Generating Process on Firm-Specific Events: A Discussion of Event Study Methods," Journal of Financial and Quantitative Analysis 20, 151-168.

Tsai, K. S., 2002, Back-Alley Banking: Private Entrepreneurs in China, Cornell University Press, Ithaca NY. 
Wang, Y., and H. Xia, 2014, "Do Lenders Still Monitor When They Can Securitize Loans?," Review of Financial Studies 27, 2354-2391.

Yook, K. C., 2003, "Larger Return to Cash Acquisitions: Signaling Effect or Leverage Effect?," Journal of Business 76, 477-449. 
Table 1: Definitions of variables.

\begin{tabular}{|c|c|c|}
\hline $\begin{array}{l}\text { Variable } \\
\text { category }\end{array}$ & Variable name & Definition \\
\hline \multirow[t]{5}{*}{ Loan } & Loan size & The amount of inter-corporate loan, in millions of RMB \\
\hline & Spread & $\begin{array}{l}\text { The annual interest rate on the inter-corporate loan over the } \\
\text { basis lending rate minus one, i.e., the interest premium over } \\
\text { the basis lending rate }\end{array}$ \\
\hline & Maturity & The maturity of the inter-corporate loan, in months \\
\hline & Guarantee & $\begin{array}{l}=1 \text { if the loan is collateralized or guaranteed by a third-party, } \\
0 \text { otherwise }\end{array}$ \\
\hline & Loan revision & $=1$ if the loan terms are revised, 0 otherwise \\
\hline \multirow[t]{5}{*}{$\begin{array}{l}\text { Counter-party } \\
\text { Firm }\end{array}$} & Intra-group loan & $\begin{array}{l}=1 \text { if the counter-party firm is a loan-announcing firm's } \\
\text { subsidiary, controlling shareholder, or belongs to the same } \\
\text { business group }\end{array}$ \\
\hline & $\begin{array}{l}\text { Counter-party } \\
\text { ownership }\end{array}$ & $\begin{array}{l}\text { A loan-announcing firm's equity ownership in the counter- } \\
\text { party firm, or the controlling shareholder's equity ownership } \\
\text { in a loan-announcing firm }\end{array}$ \\
\hline & $\begin{array}{l}\text { Counter-party } \\
\text { industry }\end{array}$ & $\begin{array}{l}=1 \text { if the industry of the counter-party firm is the same as the } \\
\text { loan-announcing firm, } 0 \text { otherwise }\end{array}$ \\
\hline & Counter-party size & The logarithm of the total assets of the counter-party firm \\
\hline & \multicolumn{2}{|c|}{$\begin{array}{l}\text { State-owned counter- }=1 \text { if the counter-party firm is state-owned, } 0 \text { otherwise } \\
\text { party }\end{array}$} \\
\hline \multirow{9}{*}{$\begin{array}{l}\text { (Loan- } \\
\text { announcing) } \\
\text { Firm }\end{array}$} & Firm size & The logarithm of total assets \\
\hline & Sales growth & The annual sales' growth rate \\
\hline & Market to book ratio & The ratio of the market value over the book value of assets \\
\hline & Cash holding & Cash over total assets \\
\hline & Free cash flow & $\begin{array}{l}\text { Operating cash flow minus capital expenditure over total } \\
\text { assets }\end{array}$ \\
\hline & Leverage & Total liabilities over total assets \\
\hline & State control & $=1$ if the ultimate owner is the state, 0 otherwise \\
\hline & $\begin{array}{l}\text { Other accounts } \\
\text { receivable }\end{array}$ & Other accounts receivable over total assets \\
\hline & $\begin{array}{l}\text { Other accounts } \\
\text { payable }\end{array}$ & Other accounts payable over total assets \\
\hline
\end{tabular}


Table 2: Descriptive statistics on the announcement of inter-corporate loans. Panel A: Distribution of inter-corporate loan announcements by year and type

\begin{tabular}{lccc}
\hline Year & All & Issuance & Receipt \\
\hline 2005 & 15 & 11 & 4 \\
2006 & 26 & 18 & 8 \\
2007 & 39 & 31 & 8 \\
2008 & 91 & 74 & 17 \\
2009 & 93 & 73 & 20 \\
2010 & 123 & 90 & 33 \\
2011 & 180 & 133 & 47 \\
2012 & 152 & 134 & 18 \\
\hline Total & 719 & 564 & 155 \\
\hline
\end{tabular}

Panel B: Distribution of inter-corporate loan announcements by industry

\begin{tabular}{lccc}
\hline Industry names & All & Issuance & Receipt \\
\hline Agriculture, forestry, animal husbandry and & 9 & 9 & 0 \\
fishery & & & \\
Mining & 43 & 41 & 2 \\
Manufacturing & 337 & 264 & 73 \\
Utilities & 67 & 55 & 12 \\
Construction & 10 & 7 & 3 \\
Transportation & 29 & 22 & 7 \\
Information technology & 28 & 26 & 2 \\
Wholesale and retail trade & 51 & 48 & 3 \\
Real estate & 76 & 35 & 41 \\
Social service & 46 & 42 & 4 \\
Communication and culture & 5 & 5 & 0 \\
Comprehensive & 18 & 10 & 8 \\
\hline Total & 719 & 564 & 155 \\
\hline
\end{tabular}


Table 3: Characteristics of inter-corporate loans.

Loan size is the amount of inter-corporate loans in millions of RMB; Maturity is the loan maturity in numbers of months; Spread is the percentage increase in the interest rate from the basis lending rate; Guarantee equals one if a loan is collateralized or guaranteed by a third party, zero otherwise. Loan revision equals one if the loan terms are revised, zero otherwise. The test of mean difference between issuance and receipt reports the t-statistics with significance $* * *$ at one percent, $* *$ at five percent, and $*$ at ten percent level.

Panel A: all inter-corporate loans

\begin{tabular}{|c|c|c|c|c|c|c|c|}
\hline & \multicolumn{3}{|c|}{ Issuance } & \multicolumn{3}{|c|}{ Receipt } & \multirow{2}{*}{$\frac{\text { Test of mean difference }}{\text { T-stat }}$} \\
\hline & \# Obs. & Mean & Median & \# Obs. & Mean & Median & \\
\hline & \multicolumn{6}{|c|}{ All loans } & \\
\hline Loan size & 564 & 185.23 & 70 & 155 & 300.26 & 180 & $-2.59 * * *$ \\
\hline Maturity & 500 & 16.29 & 12 & 146 & 18.99 & 12 & $-2.14 * *$ \\
\hline Spread & 452 & 0.45 & 0.06 & 143 & 0.05 & 0 & $6.24 * * *$ \\
\hline Guarantee & 564 & 0.29 & 0 & 155 & 0.12 & 0 & $4.19 * * *$ \\
\hline \multirow[t]{2}{*}{ Loan revision } & 564 & 0.11 & 0 & 155 & 0.10 & 0 & 0.47 \\
\hline & \multicolumn{6}{|c|}{ Intra-group loans } & \\
\hline Loan size & 396 & 216.57 & 80 & 140 & 298.28 & 150 & -1.50 \\
\hline Maturity & 339 & 18.22 & 12 & 134 & 19.07 & 12 & -0.57 \\
\hline Spread & 312 & 0.14 & 0 & 132 & 0.04 & 0 & $2.44 * *$ \\
\hline Guarantee & 396 & 0.13 & 0 & 140 & 0.09 & 0 & 1.05 \\
\hline \multirow[t]{2}{*}{ Loan revision } & 396 & 0.11 & 0 & 140 & 0.11 & 0 & 0.05 \\
\hline & \multicolumn{6}{|c|}{ Inter-group loans } & \\
\hline Loan size & 168 & 111.36 & 60 & 15 & 318.80 & 200 & $-3.97 * * *$ \\
\hline Maturity & 161 & 12.24 & 12 & 12 & 18.17 & 12 & $-2.44 * *$ \\
\hline Spread & 140 & 1.15 & 1.21 & 11 & 0.17 & 0 & $3.79 * * *$ \\
\hline Guarantee & 168 & 0.66 & 1 & 15 & 0.40 & 0 & $2.03 * *$ \\
\hline Loan revision & 168 & 0.11 & 0 & 15 & 0 & 0 & 1.38 \\
\hline \multicolumn{8}{|c|}{ Panel B: subsample of intra-group loans } \\
\hline & \multicolumn{6}{|c|}{ To/from controlling shareholders } & \\
\hline Loan size & 4 & 189.50 & 340 & 105 & 305.09 & 200 & -0.55 \\
\hline Maturity & 4 & 9.75 & 12 & 104 & 19.09 & 12 & -1.19 \\
\hline Spread & 4 & 0.12 & 0 & 102 & 0.01 & 0 & 0.79 \\
\hline Guarantee & 4 & 0 & 0 & 105 & 0.10 & 0 & -0.64 \\
\hline \multirow[t]{2}{*}{ Loan revision } & 4 & 0 & 0 & 105 & 0.08 & 0 & -0.57 \\
\hline & \multicolumn{6}{|c|}{ To/from subsidiaries } & \\
\hline Loan size & 375 & 216.93 & 80 & 10 & 165.50 & 80 & 0.27 \\
\hline Maturity & 324 & 18.51 & 12 & 9 & 12.67 & 12 & 1.20 \\
\hline Spread & 294 & 0.12 & 0 & 8 & 0.18 & 0 & -0.40 \\
\hline Guarantee & 375 & 0.12 & 0 & 10 & 0 & 0 & 1.16 \\
\hline \multirow[t]{2}{*}{ Loan revision } & 375 & 0.11 & 0 & 10 & 0 & 0 & 1.09 \\
\hline & \multicolumn{6}{|c|}{ To borrowers/from lenders with other relationship } & \\
\hline Loan size & 16 & 225.25 & 60.10 & 25 & 322.80 & 100 & -0.49 \\
\hline Maturity & 10 & 12.60 & 12 & 21 & 21.71 & 12 & $-1.64 *$ \\
\hline Spread & 13 & 0.40 & 0.10 & 22 & 0.11 & 0 & 1.26 \\
\hline Guarantee & 16 & 0.31 & 0 & 25 & 0.12 & 0 & 1.52 \\
\hline Loan revision & 16 & 0.19 & 0 & 25 & 0.28 & 0 & -0.66 \\
\hline
\end{tabular}




\section{Table 4: The determinants of issuance / receipt of inter-corporate loans.}

The dependent variable is loan issuance / receipt which equals 1 if a firm issues/receives an inter-corporate loan, 0 otherwise. Firm age is the logarithm of the firm age; Market to book ratio is market value of equity plus book value of total liabilities scaled by book value of total assets; Leverage is total liabilities over total assets; State-control equals one if the ultimate controller of the firm is state-owned, zero otherwise. CEO also chairman equals 1 if the CEO is also the chairman of the board, 0 otherwise. Coefficients are reported with robust standard errors in parentheses. Significance indicated as *** at one, $* *$ at five, and * at ten percent level.

\begin{tabular}{|c|c|c|c|c|c|c|}
\hline & \multicolumn{3}{|c|}{ Issuance } & (4) & Receiving & (6) \\
\hline & Full sample & Intra-group & Inter-group & Full sample & Intra-group & Inter-group \\
\hline Firm age & $\begin{array}{l}-0.01 \\
(0.01)\end{array}$ & $\begin{array}{c}-0.03 * * \\
(0.01)\end{array}$ & $\begin{array}{l}0.03^{*} \\
(0.02)\end{array}$ & $\begin{array}{l}-0.01 \\
(0.02)\end{array}$ & $\begin{array}{c}0.01 \\
(0.02)\end{array}$ & $\begin{array}{c}-0.19 * * \\
(0.08)\end{array}$ \\
\hline Market to book ratio & $\begin{array}{l}-0.07^{*} \\
(0.04)\end{array}$ & $\begin{array}{l}-0.04 \\
(0.05)\end{array}$ & $\begin{array}{c}-0.12 * * \\
(0.05)\end{array}$ & $\begin{array}{c}0.03 \\
(0.04)\end{array}$ & $\begin{array}{l}-0.01 \\
(0.05)\end{array}$ & $\begin{array}{c}0.55^{* * *} \\
(0.18)\end{array}$ \\
\hline Leverage & $\begin{array}{c}-1.03 * * * \\
(0.16)\end{array}$ & $\begin{array}{l}-0.48 \\
(0.32)\end{array}$ & $\begin{array}{c}-2.24 * * * \\
(0.38)\end{array}$ & $\begin{array}{c}0.52 \\
(0.67)\end{array}$ & $\begin{array}{c}0.29 \\
(0.69)\end{array}$ & $\begin{array}{l}8.46^{*} \\
(4.98)\end{array}$ \\
\hline State control & $\begin{array}{c}0.37 * * * \\
(0.09)\end{array}$ & $\begin{array}{c}0.53^{* * *} \\
(0.15)\end{array}$ & $\begin{array}{c}0.13 \\
(0.16)\end{array}$ & $\begin{array}{c}0.34^{* * * *} \\
(0.11)\end{array}$ & $\begin{array}{c}0.38^{* * *} \\
(0.14)\end{array}$ & $\begin{array}{l}-0.23 \\
(1.05)\end{array}$ \\
\hline EBIT & $\begin{array}{l}-0.59 \\
(1.04)\end{array}$ & $\begin{array}{l}-0.19 \\
(1.18)\end{array}$ & $\begin{array}{l}-1.44 \\
(1.84)\end{array}$ & $\begin{array}{c}0.77 \\
(2.07)\end{array}$ & $\begin{array}{c}1.19 \\
(2.27)\end{array}$ & $\begin{array}{l}-22.41^{*} \\
(11.64)\end{array}$ \\
\hline CEO also chairman & $\begin{array}{c}-0.40 * * * \\
(0.12)\end{array}$ & $\begin{array}{c}-0.82 * * * \\
(0.32)\end{array}$ & $\begin{array}{c}0.10 \\
(0.20)\end{array}$ & $\begin{array}{l}-0.30 \\
(0.21)\end{array}$ & $\begin{array}{l}-0.26 \\
(0.18)\end{array}$ & $\begin{array}{l}-1.25 \\
(0.81)\end{array}$ \\
\hline Constant & $\begin{array}{c}0.77 * * * \\
(0.26)\end{array}$ & $\begin{array}{l}0.56^{*} \\
(0.31)\end{array}$ & $\begin{array}{c}1.05 * * * \\
(0.35)\end{array}$ & $\begin{array}{l}-0.26 \\
(0.56)\end{array}$ & $\begin{array}{l}-0.38 \\
(0.63)\end{array}$ & $\begin{array}{l}-1.91 \\
(2.19)\end{array}$ \\
\hline Observations & 486 & 317 & 181 & 161 & 136 & 25 \\
\hline Pseudo R2 & 0.049 & 0.075 & 0.109 & 0.025 & 0.025 & 0.357 \\
\hline
\end{tabular}




\section{Table 5: CARs on the issuance of inter-corporate loans.}

Inter-corporate loans are classified as single-events if there is a single announcement for issuing a loan on the same date, and vice versa for multipleevents. The t-test of the CARs reports the t-statistic, and the Wilcoxon signedrank test report the proportion of positive CARs. Significance is indicated as *** at one percent, $* *$ at five percent, and $*$ at ten percent level.

\begin{tabular}{lccccc}
\hline & \# Obs & Mean & \multicolumn{4}{l}{ Median } & T-stat & Signed-rank test \\
\cline { 2 - 6 } All loans \\
CAR[-1,0] & 440 & -0.37 & -0.26 & $-4.14 * * *$ & $0.42 * * *$ \\
CAR[-1,1] & 440 & -0.42 & -0.41 & $-3.08 * * *$ & $0.40^{* * *}$ \\
CAR[-2,2] & 440 & -0.49 & -0.56 & $-2.74 * * *$ & $0.42 * * *$ \\
\hline & 440 & -0.70 & -0.59 & $-3.02 * * *$ & $0.42 * * *$ \\
AR[0] & & \multicolumn{5}{c}{ Single event } \\
CAR[-1,0] & 350 & -0.40 & -0.31 & $-4.00 * * *$ & $0.39 * * *$ \\
CAR[-1,1] & 350 & -0.48 & -0.56 & $-3.07 * * *$ & $0.38 * * *$ \\
CAR[-2,2] & 350 & -0.51 & -0.66 & $-2.52 * *$ & $0.41 * * *$ \\
\hline & 350 & -0.67 & -0.59 & $-2.53 * *$ & $0.42 * * *$ \\
AR[0] & & & Multiple-events & \\
CAR[-1,0] & 90 & -0.26 & 0.12 & -1.28 & 0.54 \\
CAR[-1,1] & 90 & -0.17 & 0.02 & -0.65 & 0.50 \\
CAR[-2,2] & 90 & -0.41 & -0.26 & -1.08 & 0.44 \\
\hline
\end{tabular}


Table 6: CARs on the issuance for intra-group versus inter-group borrowers.

Inter-corporate loans are in the intra-group borrowers subsample if the borrowers are in the same business group, and vice versa for the inter-group borrowers subsample. The t-test of the CARs reports the t-statistic, and the Wilcoxon signedrank test reports the proportion of positive CARs. Significance is indicated as *** at one percent, $* *$ at five percent, and $*$ at ten percent level.

\begin{tabular}{lccccc}
\hline & \multicolumn{5}{c}{ Intra-group borrowers } \\
& \# Obs & Mean & Median & T-stat & Signed-rank test \\
\cline { 2 - 6 } AR[0] & 222 & -0.44 & -0.29 & $-3.71^{* * *}$ & $0.41^{* * *}$ \\
CAR[-1,0] & 222 & -0.62 & -0.43 & $-3.32^{* * *}$ & $0.39 * * *$ \\
CAR[-1,1] & 222 & -0.58 & -0.54 & $-2.44 * *$ & $0.43^{* * *}$ \\
CAR[-2,2] & 222 & -0.56 & -0.47 & $-1.82^{*}$ & $0.44 * *$ \\
\hline & & & Inter-group borrowers & \\
& \# Obs & Mean & Median & T-stat & Signed-rank test \\
\cline { 2 - 6 } AR[0] & 128 & -0.32 & -0.48 & $-1.81^{*}$ & $0.35^{* * *}$ \\
CAR[-1,0] & 128 & -0.25 & -0.63 & -0.88 & $0.36^{* * *}$ \\
CAR[-1,1] & 128 & -0.37 & -0.73 & -1.03 & $0.38^{* *}$ \\
CAR[-2,2] & 128 & -0.86 & -0.79 & $-1.75^{*}$ & $0.40^{* *}$ \\
\hline
\end{tabular}


Table 7: CARs on the issuance of intra-group loans to controlling shareholders, subsidiaries, and borrowers with other relationships.

Intra-group loans are in subsamples according to controlling shareholders, subsidiaries, and borrowers with other relationships. The t-test of the CARs reports the t-statistic, and the Wilcoxon signed-rank test reports the proportion of positive CARs. Significance is indicated as ${ }^{* * *}$ at one percent, ${ }^{* *}$ at five percent, and * at ten percent level.

\begin{tabular}{lccccc}
\hline & \multicolumn{5}{c}{ Intra-group loans to controlling shareholders } \\
& $\#$ Obs & Mean & Median & T-stat & Signed-rank test \\
\cline { 2 - 6 } AR[0] & 4 & -0.61 & -0.55 & -1.28 & 0.25 \\
CAR[-1,0] & 4 & -1.97 & -0.83 & -1.33 & 0.25 \\
CAR[-1,1] & 4 & -1.42 & -1.32 & -1.15 & 0.50 \\
CAR[-2,2] & 4 & -5.32 & -4.13 & -2.05 & $0.00^{*}$ \\
\hline \multicolumn{5}{c}{ Intra-group loans to subsidiaries } \\
AR[0] & \# Obs & Mean & Median & T-stat & Signed-rank test \\
CAR[-1,0] & 206 & -0.45 & -0.25 & $-3.64^{* * *}$ & $0.42^{* * *}$ \\
CAR[-1,1] & 206 & -0.65 & -0.43 & $-3.35^{* * *}$ & $0.38^{* * *}$ \\
CAR[-2,2] & 206 & -0.63 & -0.54 & $-2.48^{* *}$ & $0.43^{* * *}$ \\
\hline & 206 & -0.51 & -0.47 & -1.60 & $0.44^{* *}$ \\
AR[0] & Intra-group loans to borrowers with other relationships \\
CAR[-1,0] & $\#$ Obs & Mean & Median & T-stat & Signed-rank test \\
CAR[-1,1] & 12 & -0.17 & -0.54 & -0.35 & -0.42 \\
CAR[-2,2] & 12 & 0.43 & -0.32 & 0.67 & 0.50 \\
\hline
\end{tabular}




\section{Table 8: CARs on the receipt of inter-corporate loans.}

Inter-corporate loans are classed as single-events if there is a single announcement of a loan receipt on the same date, and as multiple-events if there are multiple announcements of loan receipts on the same date. The t-test of the CARs reports the t-statistic, and the Wilcoxon signed-rank test reports the proportion of positive CARs. Significance is indicated as $* * *$ at one percent, $* *$ at five percent, and $*$ at ten percent level.

\begin{tabular}{lccccc}
\hline & \# Obs & Mean & Median & T-stat & Signed-rank test \\
\cline { 2 - 6 } AR[0] & 140 & 0.35 & 0.04 & 1.45 & 0.51 \\
CAR[-1,0] & 140 & 0.91 & 0.10 & $2.67^{* * *}$ & $0.51^{*}$ \\
CAR[-1,1] & 140 & 1.01 & 0.49 & $2.55^{* *}$ & $0.54^{*}$ \\
CAR[-2,2] & 140 & 0.9 & 0.51 & $2.14^{* *}$ & $0.56^{*}$ \\
\hline \multicolumn{5}{c}{ Single event } \\
AR[0] & 125 & 0.46 & 0.18 & $1.74^{*}$ & 0.53 \\
CAR[-1,0] & 125 & 1.09 & 0.57 & $2.95^{* * *}$ & $0.54^{* *}$ \\
CAR[-1,1] & 125 & 1.31 & 0.84 & $3.04^{* * *}$ & $0.58^{* *}$ \\
CAR[-2,2] & 125 & 1.15 & 0.62 & $2.52^{* *}$ & $0.60^{* *}$ \\
\hline & 15 & -0.58 & -0.52 & $-2.14^{*}$ & $0.33^{*}$ \\
AR[0] & 15 & -0.59 & -1.34 & -0.86 & 0.33 \\
CAR[-1,0] & 15 & -1.45 & -2.02 & $-1.97^{*}$ & $0.20^{* *}$ \\
CAR[-1,1] & 15 & -1.15 & -2.36 & -1.27 & 0.27 \\
CAR[-2,2] & 15 & \multicolumn{5}{c}{ Multiple events } \\
\hline
\end{tabular}




\section{Table 9: CARs on the receipt from intra-group versus inter-group lenders.}

Inter-corporate loans are in the intra-group lenders subsample if the lenders are in the same business group, and as inter-group lenders if the lenders are not in the same business group. The t-test of the CARs reports the t-statistic, and the Wilcoxon signed-rank test reports the proportion of positive CARs. Significance is indicated as $* * *$ at one percent, $* *$ at five percent, and * at ten percent level.

\begin{tabular}{lccccc}
\hline & & \multicolumn{5}{c}{ Intra-group lenders } \\
AR[0] & \# Obs & Mean & Median & T-stat & Signed-rank test \\
\cline { 2 - 6 } CAR[-1,0] & 110 & 0.43 & 0.18 & $1.69^{*}$ & 0.54 \\
CAR[-1,1] & 110 & 1.06 & 0.62 & $2.79^{* * *}$ & $0.55^{* *}$ \\
CAR[-2,2] & 110 & 1.19 & 0.81 & $2.76^{* * *}$ & $0.59^{* *}$ \\
\hline & 110 & 1.04 & 0.6 & $2.12^{* *}$ & $0.58^{*}$ \\
\hline AR[0] & & & Inter-group lenders & \\
CAR[-1,0] & 15 & 0.68 & -0.73 & 0.56 & Signed-rank test \\
CAR[-1,1] & 15 & 1.33 & -0.03 & 0.97 & 0.47 \\
CAR[-2,2] & 15 & 2.16 & 1.42 & 1.26 & 0.40 \\
\hline
\end{tabular}


Table 10: CARs on the receipt of intra-group loans from controlling shareholders, subsidiaries, and lenders with other relationship.

Intra-group loans are in subsamples according to controlling shareholders, subsidiaries, and borrowers with other relationship. The t-test of the CARs reports the t-statistic, and the Wilcoxon signed-rank test reports the proportion of positive CARs. Significance is indicated as $* * *$ at one percent, $* *$ at five percent, and $*$ at ten percent level.

\begin{tabular}{lccccc}
\hline & \multicolumn{5}{c}{ Intra-group loans from controlling shareholders } \\
& \# Obs & Mean & Median & T-stat & Signed-rank test \\
\cline { 2 - 6 } AR[0] & 81 & 0.55 & 0.30 & $1.99^{*}$ & 0.58 \\
CAR[-1,0] & 81 & 1.42 & 0.72 & $3.07 * * *$ & $0.58^{* * *}$ \\
CAR[-1,1] & 81 & 1.70 & 0.85 & $3.12^{* * *}$ & $0.60^{* * *}$ \\
CAR[-2,2] & 81 & 1.54 & 1.15 & $2.53^{* *}$ & $0.60^{* *}$ \\
\hline & \multicolumn{7}{c}{ Intra-group loans from subsidiaries } \\
& \# Obs & Mean & Median & T-stat & Signed-rank test \\
AR[0] & 7 & -0.6 & -1.14 & -1.13 & 0.29 \\
CAR[-1,0] & 7 & -0.98 & -1.35 & -0.96 & 0.43 \\
CAR[-1,1] & 7 & -1.15 & -1.75 & -0.93 & 0.43 \\
CAR[-2,2] & 7 & -2.23 & -1.96 & -1.46 & 0.43 \\
\hline & \multicolumn{7}{c}{ Intra-group loans from lenders with other relationship } \\
AR[0] & Obs & Mean & Median & T-stat & Signed-rank test \\
\cline { 2 - 6 } CAR[-1,0] & 22 & 0.28 & -0.06 & 0.39 & 0.45 \\
CAR[-1,1] & 22 & 0.37 & -0.08 & 0.51 & 0.50 \\
CAR[-2,2] & 22 & 0.04 & 0.72 & 0.07 & 0.59 \\
\hline
\end{tabular}




\section{Table 11: The regression of CAR[-1,0] on loan, counter-party and firm characteristics.}

The dependent variable is the CAR[-1,0] in percentage points. Log loan size is the logarithm of the amount of inter-corporate loans in millions of RMB; Log maturity is the logarithm of the loan maturity in number of months; Spread is the percentage increase in the interest rate from the basis lending rate; Guarantee equals one if a loan is collateralized or guaranteed by a third party, zero otherwise; Loan revision equals one if a loan revises the previous loan terms, zero otherwise; Intra-group loan equals one if the counter-party is in a same business group, zero otherwise; Counter-party industry equals one if the counterparty and loan-announcing firm are in the same industry, zero otherwise; Counter-party size is the logarithm of total assets of the counter-party; State-owned counter-party equals one if the counter-party is state-owned, zero otherwise; Firm size is the logarithm of total assets; Age is the number of years listed in the stock exchanges; Market to book ratio is the market value of equity plus the book value of total liabilities scaled by the book value of total assets; Free cash flow is the free cash flow over total assets; Leverage is the total liabilities over total assets; State-control equals one if the ultimate controller of the firm is state-owned, zero otherwise; Other accounts receivable is the other accounts receivable over total assets; Other accounts payable is the other accounts payable over total assets. Industry and year dummies are included and the coefficients are omitted. Coefficients are reported with robust standard errors in parentheses. Significance is indicated as *** at one percent, ** at five percent, and * at ten percent level.

Issuance of inter-corporate loans

\begin{tabular}{|c|c|c|c|c|c|c|c|c|c|}
\hline & & $(1)$ & $(2)$ & (3) & $(4)$ & $(5)$ & (6) & (7) & $(8)$ \\
\hline \multirow[t]{10}{*}{ Loan } & \multirow[t]{2}{*}{ Log loan size } & -0.10 & -0.04 & -0.21 & -0.08 & -0.52 & 0.01 & 0.40 & 1.16 \\
\hline & & $(0.17)$ & $(0.23)$ & $(0.21)$ & $(0.26)$ & $(0.54)$ & $(0.65)$ & $(0.44)$ & $(1.15)$ \\
\hline & \multirow[t]{2}{*}{ Spread } & $-0.69 * *$ & $-0.90 *$ & $-0.65^{*}$ & $-1.10^{* *}$ & -1.19 & $-5.44 *$ & -0.05 & $-11.42 *$ \\
\hline & & $(0.30)$ & $(0.49)$ & $(0.37)$ & $(0.53)$ & $(1.81)$ & $(2.78)$ & $(2.16)$ & $(5.75)$ \\
\hline & \multirow[t]{2}{*}{ Log maturity } & 0.24 & 0.04 & 0.33 & 0.00 & -0.50 & -0.40 & -0.67 & 0.28 \\
\hline & & $(0.35)$ & $(0.43)$ & $(0.40)$ & $(0.49)$ & $(0.93)$ & $(1.09)$ & $(0.95)$ & $(1.31)$ \\
\hline & \multirow[t]{2}{*}{ Guarantee } & 0.62 & 0.72 & 0.84 & 0.95 & -0.31 & 0.93 & 1.69 & 2.91 \\
\hline & & $(0.43)$ & $(0.54)$ & $(0.53)$ & $(0.62)$ & (1.47) & $(2.30)$ & $(1.31)$ & $(2.91)$ \\
\hline & \multirow[t]{2}{*}{ Loan revision } & -0.64 & -1.04 & -0.62 & -1.11 & 1.48 & 0.58 & 2.00 & -1.10 \\
\hline & & $(0.76)$ & $(0.90)$ & $(0.84)$ & $(0.92)$ & (1.55) & (1.48) & (1.89) & $(2.35)$ \\
\hline \multirow[t]{8}{*}{ Counter-party } & \multirow[t]{2}{*}{ Intra-group loan } & & $-1.64 * *$ & & $-1.74 * *$ & & -0.20 & & -0.09 \\
\hline & & & $(0.78)$ & & $(0.84)$ & & $(3.81)$ & & $(6.09)$ \\
\hline & \multirow[t]{2}{*}{ Counter-party industry } & & 0.22 & & 0.19 & & 0.46 & & 1.17 \\
\hline & & & $(0.57)$ & & $(0.59)$ & & $(1.35)$ & & (1.99) \\
\hline & \multirow[t]{2}{*}{ Counter-party size } & & -0.14 & & -0.23 & & 0.20 & & -0.36 \\
\hline & & & $(0.14)$ & & $(0.15)$ & & $(0.35)$ & & $(0.52)$ \\
\hline & \multirow[t]{2}{*}{ State-owned counter-party } & & 0.73 & & 0.72 & & -1.86 & & $-7.40^{* *}$ \\
\hline & & & $(0.52)$ & & $(0.62)$ & & $(1.99)$ & & $(3.28)$ \\
\hline \multirow{21}{*}{$\begin{array}{l}\text { (Loan- } \\
\text { announcing) } \\
\text { Firm }\end{array}$} & \multirow[t]{2}{*}{ Firm size } & & & -0.01 & -0.08 & & & -0.55 & -1.03 \\
\hline & & & & $(0.26)$ & $(0.29)$ & & & $(0.78)$ & $(1.50)$ \\
\hline & \multirow[t]{2}{*}{ Age } & & & $0.10 * *$ & $0.10^{*}$ & & & -0.03 & -0.30 \\
\hline & & & & $(0.05)$ & $(0.06)$ & & & $(0.14)$ & $(0.32)$ \\
\hline & \multirow[t]{2}{*}{ Market to book ratio } & & & -0.06 & $-0.42 *$ & & & 0.09 & 0.43 \\
\hline & & & & $(0.24)$ & $(0.24)$ & & & $(0.65)$ & $(1.05)$ \\
\hline & \multirow[t]{2}{*}{ Free cash flow } & & & -0.81 & -1.58 & & & -2.14 & -9.27 \\
\hline & & & & $(1.02)$ & $(1.37)$ & & & $(4.64)$ & $(7.30)$ \\
\hline & \multirow[t]{2}{*}{ Leverage } & & & -0.46 & -1.16 & & & $-6.09 *$ & -6.47 \\
\hline & & & & $(1.58)$ & $(2.03)$ & & & $(3.38)$ & $(5.80)$ \\
\hline & \multirow[t]{2}{*}{ State control } & & & 0.04 & -0.19 & & & 1.04 & $9.04 *$ \\
\hline & & & & $(0.50)$ & $(0.59)$ & & & $(1.44)$ & $(4.70)$ \\
\hline & \multirow[t]{2}{*}{ Other accounts receivable } & & & $-11.57 * *$ & $-14.49 * *$ & & & & \\
\hline & & & & $(5.83)$ & $(7.16)$ & & & & \\
\hline & \multirow[t]{2}{*}{ Other accounts payable } & & & & & & & 4.19 & 7.07 \\
\hline & & & & & & & & $(3.50)$ & $(8.65)$ \\
\hline & \multirow[t]{2}{*}{ Constant } & 2.71 & 3.19 & 3.22 & 6.34 & 9.58 & 4.21 & 18.14 & 23.05 \\
\hline & & $(1.85)$ & $(2.60)$ & $(5.51)$ & $(5.94)$ & $(6.49)$ & $(10.24)$ & (16.64) & $(34.72)$ \\
\hline & Industry and year dummie & Yes & Yes & Yes & Yes & Yes & Yes & Yes & Yes \\
\hline & Observations & 277 & 207 & 259 & 194 & 92 & 57 & 86 & 53 \\
\hline & R-squared & 0.117 & 0.192 & 0.141 & 0.234 & 0.301 & 0.429 & 0.499 & 0.668 \\
\hline
\end{tabular}

Receipt of inter-corporate loans 


\section{Table 12: Capital expenditure ex post inter-corporate loan}

CAPX is capital expenditure scaled by the total assets in the year before loan announcement. [-1]/[0]/[+1]/[+2] indicates the number of years before / after the inter-corporate loan announcement. $160 / 84$ observations are included for intragroup / inter-group loans respectively for the issue, and $72 / 12$ observations are included for the receive. The t-test of the mean difference reports the t-statistic. Significance is indicated as $* * *$ at one percent, ${ }^{* *}$ at five percent, and $*$ at ten percent level.

\begin{tabular}{|c|c|c|c|c|}
\hline & \multicolumn{2}{|c|}{ Issue } & \multicolumn{2}{|c|}{ Receive } \\
\hline & Mean & St.Dev & Mean & St.Dev \\
\hline \multicolumn{5}{|l|}{ CAPX $[+1,+2]-$ CAPX $[-1,0]$} \\
\hline Intra-group loans & $-0.0285 * *$ & 0.0111 & -0.0039 & 0.0123 \\
\hline High MB & $-0.0453 * *$ & 0.0195 & -0.0064 & 0.0223 \\
\hline Low MB & -0.0117 & 0.0107 & -0.0014 & 0.0108 \\
\hline T-test of high MB vs low $M$ & -0.0336 & 0.0222 & -0.0050 & 0.0247 \\
\hline Inter-group loans & -0.0089 & 0.0059 & 0.1833 & 0.1991 \\
\hline High MB & $-0.0245 * * *$ & 0.0091 & 0.3456 & 0.3999 \\
\hline Low MB & 0.0067 & 0.0070 & 0.0210 & 0.0624 \\
\hline T-test of high MB vs low M & $-0.0312 * * *$ & 0.0114 & 0.3246 & 0.4048 \\
\hline \multicolumn{5}{|c|}{ T-test of intra-group vs inter-group loans } \\
\hline & -0.0196 & 0.016 & $-0.1872 * *$ & 0.0844 \\
\hline
\end{tabular}




\section{Table 13: ROA ex post inter-corporate loan announcements.}

ROA is net income over total assets. [-1] / [+2] indicates the number of years before / after the inter-corporate loan announcement. 168/92 observations are included for intra-group / inter-group loans respectively for the issue, and $76 / 14$ for the receive. The t-test of the mean difference reports the $\mathrm{t}$-statistic. Significance is indicated as $* * *$ at one percent, $* *$ at five percent, and * at ten percent level.

\begin{tabular}{|c|c|c|c|c|}
\hline & \multicolumn{2}{|c|}{ Issue } & \multicolumn{2}{|c|}{ Receive } \\
\hline & Mean & St.Dev & Mean & St.Dev \\
\hline \multicolumn{5}{|l|}{$\operatorname{ROA}[+2]-\operatorname{ROA}[-1]$} \\
\hline Intra-group loans & $-0.0174 * * *$ & 0.0042 & 0.0099 & 0.0087 \\
\hline High MB & $-0.0247 * * *$ & 0.0055 & 0.0189 & 0.0154 \\
\hline Low MB & -0.0100 & 0.0062 & 0.0008 & 0.0083 \\
\hline T-test of high MB vs low M & $-0.0146^{*}$ & 0.0083 & 0.0181 & 0.0175 \\
\hline Inter-group loans & -0.0082 & 0.0067 & -0.0122 & 0.0101 \\
\hline High MB & $-0.0235^{* *}$ & 0.0107 & -0.0165 & 0.0184 \\
\hline Low MB & 0.0071 & 0.0077 & -0.0080 & 0.0100 \\
\hline T-test of high MB vs low M & $-0.0305 * *$ & 0.0132 & -0.0085 & 0.0210 \\
\hline \multicolumn{5}{|c|}{ T-test of intra-group vs inter-group loans } \\
\hline & -0.0091 & 0.0075 & 0.0221 & 0.0209 \\
\hline
\end{tabular}


Appendix 


\begin{tabular}{|c|c|c|c|c|}
\hline Date & Type & Name & Note & Institution \\
\hline $12 / 30 / 1992$ & Entrusted loan & $\begin{array}{l}\text { A reply to the ICBC on the issues of } \\
\text { entrusted loan }\end{array}$ & $\begin{array}{l}\text { It clarifies several issues on entrusted loans correspondingly the } \\
\text { request of the Industrial and Commercial Bank of China } \\
\text { (ICBC), e.g. the definition of entrusted loans. }\end{array}$ & $\mathrm{PBC}$ \\
\hline $5 / 16 / 1996$ & $\begin{array}{l}\text { Litigation } \\
\text { guidance }\end{array}$ & $\begin{array}{l}\text { A reply to Sichuan People's Higher Court } \\
\text { on the qualification of subjects in the } \\
\text { entrusted loan contracts }\end{array}$ & $\begin{array}{l}\text { It specifies the rules for the subjects in the litigation cases on } \\
\text { entrusted loan contracts corresponding a request by the Sichuan } \\
\text { People's Higher Court. }\end{array}$ & PSC \\
\hline $8 / 1 / 1996$ & Entrusted loan & General rules on loans & It specifies detailed rules on entrusted loans. & PBC \\
\hline $12 / 13 / 1997$ & $\begin{array}{l}\text { Litigation } \\
\text { guidance }\end{array}$ & $\begin{array}{l}\text { Issues on the litigation cases on certificates } \\
\text { of deposit }\end{array}$ & $\begin{array}{l}\text { It specifies several rules for the disputes in entrusted loan } \\
\text { contracts. }\end{array}$ & PSC \\
\hline $1 / 1 / 1998$ & $\begin{array}{l}\text { Disclosure } \\
\text { requirements }\end{array}$ & $\begin{array}{l}\text { Regulations of IPO by Shanghai and } \\
\text { Shenzhen Stock Exchange }\end{array}$ & $\begin{array}{l}\text { It specifies the disclosure requirement on entrusted loans, and } \\
\text { also related party transactions. It has been revised seven times, } \\
\text { and the latest version is effective from July } 2012 \text {. }\end{array}$ & $\begin{array}{l}\text { SSC and } \\
\text { SZSE }\end{array}$ \\
\hline 4/1/1999 & $\begin{array}{l}\text { Interest rate } \\
\text { lateralization }\end{array}$ & Interest rate regulations of $\mathrm{RMB}$ & $\begin{array}{l}\text { It specifies the regulations for the interest rate of deposits and } \\
\text { loans denominated in } \mathrm{RMB} \text {. }\end{array}$ & PBC \\
\hline $4 / 5 / 2000$ & Entrusted loan & $\begin{array}{l}\text { Notice on the issues for entrusted loan by } \\
\text { commercial banks }\end{array}$ & $\begin{array}{l}\text { It specifies a definition of entrusted loans, and switches the } \\
\text { approval system to the registration system for entrusted loans. }\end{array}$ & $\mathrm{PBC}$ \\
\hline $10 / 19 / 2005$ & Entrusted loans & $\begin{array}{l}\text { Notice on the CSRC suggestion on } \\
\text { enhancing the quality of listed firms }\end{array}$ & $\begin{array}{l}\text { It prohibits the entrusted loans from the listed firms to the } \\
\text { controlling shareholders. }\end{array}$ & $\mathrm{SCC}$ \\
\hline $10 / 27 / 2005$ & $\begin{array}{l}\text { Disclosure } \\
\text { requirements }\end{array}$ & China securities law & $\begin{array}{l}\text { It specifies the types of major events that should be } \\
\text { announcement timely in Article of } 67 \text { at Chapter } 3 \text {, e.g. } \\
\text { entrusted loan. }\end{array}$ & NPC \\
\hline $2 / 2 / 2007$ & $\begin{array}{l}\text { Disclosure } \\
\text { requirements }\end{array}$ & $\begin{array}{l}\text { Explanatory notice on the regulations on } \\
\text { information disclosure of listed firms }\end{array}$ & $\begin{array}{l}\text { It specifies the information disclosure of extraordinary items for } \\
\text { listed firms, e.g., entrusted loans. }\end{array}$ & CSRC \\
\hline $7 / 19 / 2013$ & $\begin{array}{l}\text { Interest rate } \\
\text { lateralization }\end{array}$ & $\begin{array}{l}\text { Notice on the further reform for the } \\
\text { marketization of interest rate }\end{array}$ & $\begin{array}{l}\text { It lifts the regulation on the floor of the lending interest rate, } \\
\text { and also the ceiling of the lending interest rate for rural credit } \\
\text { cooperatives. }\end{array}$ & $\mathrm{PBC}$ \\
\hline $12 / 10 / 2013$ & Entrusted loan & $\begin{array}{l}\text { Notice on several issues of tightening the } \\
\text { regulation on shadow banking }\end{array}$ & $\begin{array}{l}\text { It tightens the regulation for the shadow banking system } \\
\text { including entrusted loans }\end{array}$ & $\mathrm{SCC}$ \\
\hline
\end{tabular}

Abbreviations: NPC is the National People's Council; PBC is People's Bank of China; PSC is the People's Supreme Court; SSC is the Shanghai Stock Exchange; SZSC is the Shenzhen Stock Exchange. SCC is the State Council of China; CSRC is the China Securities Regulatory Commission. 


\section{Appendix 2: Market shares of financing sources in China.}

The upper panel shows the proportion of inter-corporate loan over total financing (left-axis, in percentage points) and the trend of total financing (right axis, in trillions of RMB), and the bottom panel shows the market share of various types of financing in the total financing of 2013. Data is retrieved from the PBOC website.
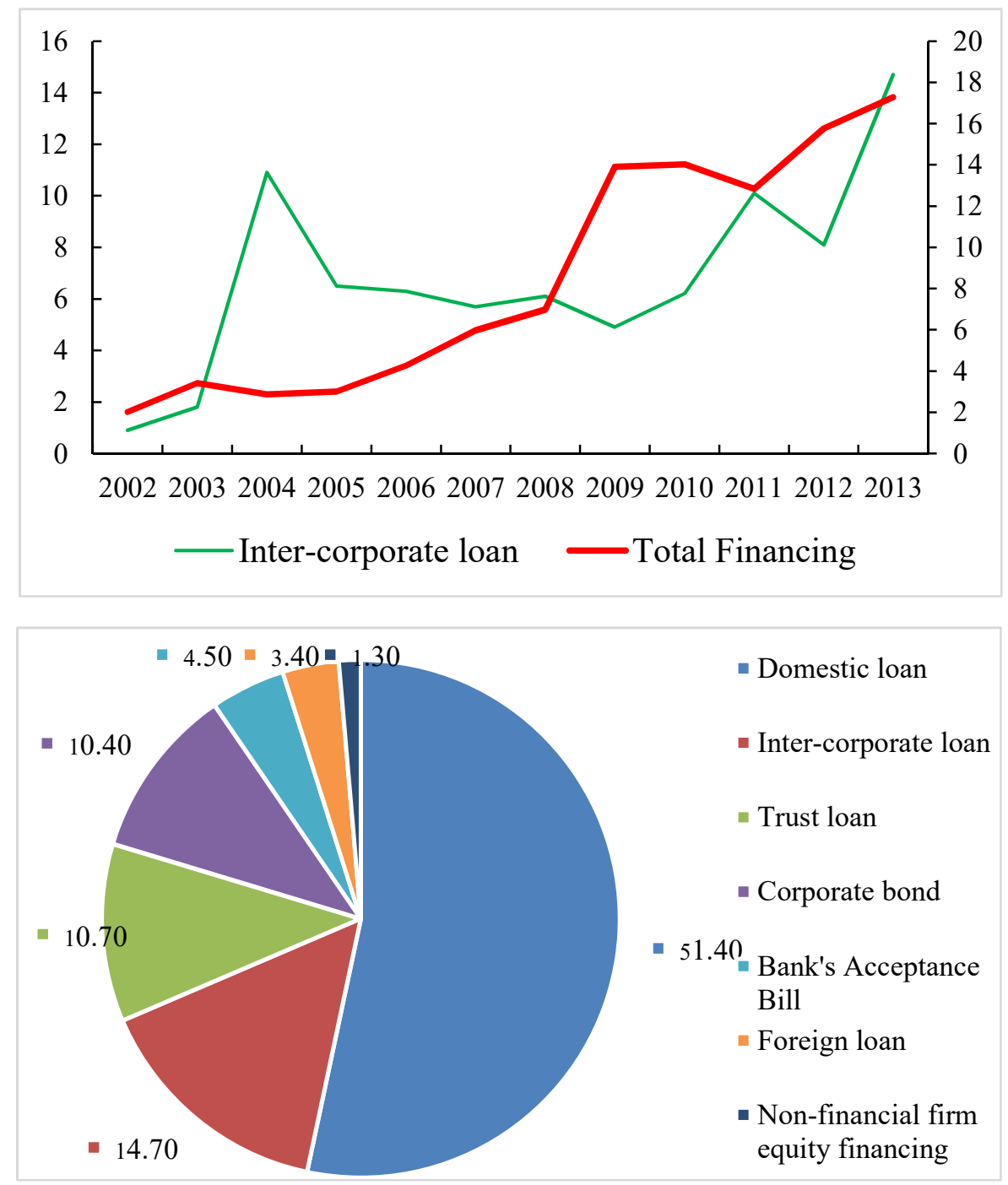


\title{
Appendix 3: Translation of an inter-corporate loan announcement.
}

\author{
Stock abbreviation: Guiyan Boye Stock code: $600459 \quad$ No: Temporary 2011-4
}

Announcement of an entrusted loan to a fully owned subsidiary

The board of directors and all members declare that this announcement contains no false documentation, misleading statement or omission of important items, and bare individual and joint liability for the truthfulness, validity and completeness of the announcement.

\section{Important notices for the entrusted loan}

Financial institution: Kunming branch, China Citic Bank

Borrower: Guiyan Yimen Ziyuan Ltd (hereafter Yimen Ziyuan Ltd)

Amount: 30 million RMB

Maturity: One year

Interest rate: 7.07 percent per year

\section{Summary}

On Feb $25^{\text {th }}, 2011$, the eighth session of the fourth board meeting of the listed firm passes the proposal of providing an entrusted loan to a fully owned subsidiary. The board agrees to extend an entrusted loan of 30 million RMB to Yimen Ziyuan Ltd. This transaction does not constitute a related transaction. This entrusted loan does not need an approval from the shareholders' meeting.

\section{Basic information about the borrower}

Yimen Ziyuan Ltd is fully owned by the listed firm Guiyan Boye. It was set up on April 1st 2010 with the approval from the Industrial and Commercial Administrative Bureau of Yimen County at Yunnan Province. It has a registered capital of 50 million RMB, with the registered address: Xiaolongkou Meishicheng, Xihuan Road, Longquan Town, Yimen County, Yuxi City, Yunnan Province. Main businesses of the firm: the development and applications of the refinery skills for the resources of precious metals; the collection and processing of second-hand resources of precious metals; the manufacturing of basic products of precious metals; the manufacturing of special powder materials; the operation of skills and products made by the listed firm (according to the approved project and maturity if the operation involves special approvals by the laws).

Up until Sep $30^{\text {th }}, 2010$, the total assets of the Yimen Ziyuan Ltd is 54.76 million RMB; the total liabilities is 4.95 million RMB; total shareholders' equity is 49.81 million RMB; net profit is $-188,000$ RMB. None of the above numbers are audited by a third party.

\section{Main content of the entrusted loan}

According to the demand of Yimen Ziyuan Ltd's operation and development, the listed firm provides an entrusted loan of 30 million RMB to Yimen Ziyuan Ltd. The loan has a maturity of one year, and an annual interest rate of 7.07 percent. (Please refer to the signed contract for the detailed items of the entrusted loan)

\section{Sources of the fund for the entrusted loan}

The fund is from the listed firm's self-owned fund. Yimen Ziyuan Ltd will repay the principal and interest in a lump sum at maturity.

\section{Purpose of the entrusted loan and its effect on the listed firm}

The entrusted loan will be used for Yimen Ziyuan Ltd's operation and development. It will not affect the listed firm's normal operation as the fund is from the self-owned fund. Yimen Ziyuan Ltd is fully owned by the listed firm, so it can repay the entrusted loan at maturity.

Here announces the transaction.

The board of Guiyan Boye Co. Ltd., 2011/2/26 
Appendix 4: The size of the entrusted loans in 2011 for firms listed on Shanghai Stock Exchange (in billions of RMB).

Data source: "An analysis on entrusted wealth management products and entrusted loans in 2011 for firms listed in Shanghai Stock Exchange" released by Shanghai Stock Exchange.

\begin{tabular}{lcccc}
\hline Categories & $\begin{array}{c}\text { Balance 2010 } \\
\text { year end }\end{array}$ & Loan issued & Loan received & $\begin{array}{c}\text { Balance 2011 } \\
\text { year end }\end{array}$ \\
\hline $\begin{array}{l}\text { Subsidiaries with a full or } \\
\text { controlling ownership }\end{array}$ & 52.77 & 65.56 & 30.25 & 88.08 \\
$\begin{array}{l}\text { Subsidiaries or joint ventures } \\
\text { without a controlling ownership }\end{array}$ & 4.18 & 5.15 & 2.87 & 6.47 \\
$\begin{array}{l}\text { Unconnected parties } \\
\text { Other connected parties }\end{array}$ & 7.26 & 14.52 & 8.34 & 13.44 \\
Total & 0.18 & 0.78 & 0.19 & 0.77 \\
\hline
\end{tabular}


Appendix 5: Average abnormal returns for issuance and receipt of inter-corporate loans in event window $[-20,20]$.
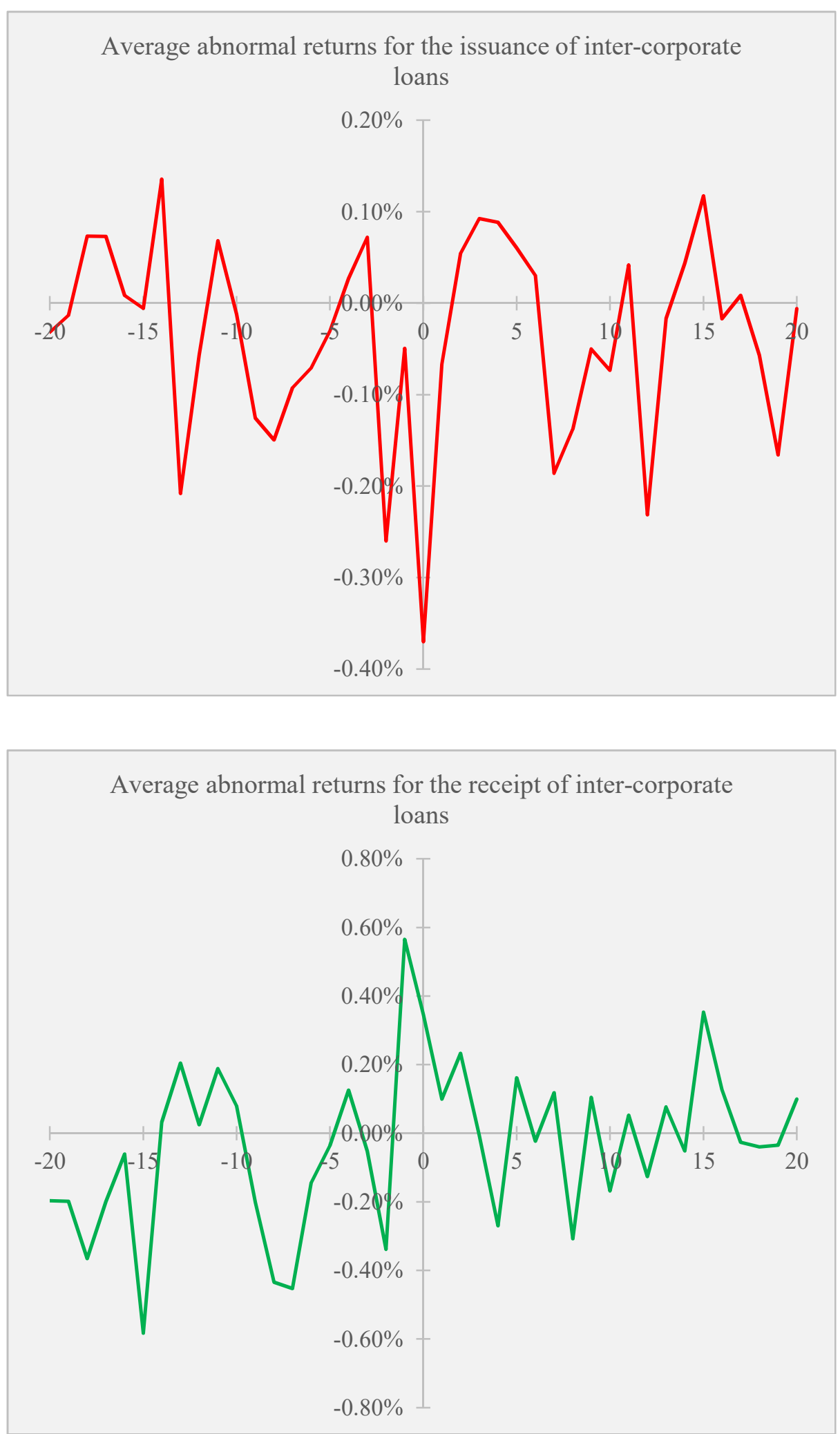


\section{Appendix 6: Summary statistics for loan, counter-party and firm characteristics.}

Log loan size is the logarithm of the amount of inter-corporate loans in millions of RMB; Log maturity is the logarithm of the loan maturity in number of months; Spread is the percentage increase of the interest rate from the basis lending rate; Guarantee equals one if a loan is collateralized or guaranteed by a third party, zero otherwise; Loan revision equals one if a loan revises previous loan terms, zero otherwise; Intra-group loan equals one if the counter-party is in the same business group, zero otherwise; Counter-party industry equals one if the counter-party and listed firm are in the same industry, zero otherwise; Counter-party size is the logarithm of total assets of the counter-party; State-owned counter-party equals one if the counterparty is state-owned, zero otherwise; Firm size is the logarithm of total assets; Age is the number of years listed on the stock exchanges; Market to book ratio is the market value of equity plus the book value of total liabilities scaled by the book value of total assets; Free cash flow is the free cash flow over total assets; Leverage is the total liabilities over total assets; State-control equals one if the ultimate controller of the firm is state-owned, zero otherwise; Other accounts receivable is the other accounts receivable over total assets; Other accounts payable is the other accounts payable over total assets. The test of mean difference is conducted between firms, with issuance/receipt of inter-corporate loans versus firms without inter-corporate loan announcements. T-statistics are reported with significance *** at one percent, ** at five percent, and * at ten percent level.

\begin{tabular}{|c|c|c|c|c|c|c|c|c|c|c|c|c|c|}
\hline \multirow{7}{*}{ Loan } & & \multicolumn{3}{|c|}{$\begin{array}{l}\text { Issuance of inter- } \\
\text { corporate loans }\end{array}$} & \multicolumn{3}{|c|}{$\begin{array}{l}\text { Receipt of inter- } \\
\text { corporate loans }\end{array}$} & \multicolumn{3}{|c|}{$\begin{array}{c}\text { No inter-corporate loan } \\
\text { firms }\end{array}$} & \multicolumn{3}{|c|}{ Test of mean difference (T-stat) } \\
\hline & & $\mathrm{N}$ & Mean & St.Dev & $\mathrm{N}$ & Mean & St.Dev & $\mathrm{N}$ & Mean & St.Dev & $\begin{array}{l}\text { Issuance v.s. } \\
\text { No loans }\end{array}$ & $\begin{array}{l}\text { Receipt v.s. } \\
\text { No loans }\end{array}$ & $\begin{array}{c}\text { Issuance v.s. } \\
\text { Receipt }\end{array}$ \\
\hline & Log loan size & 338 & 4.39 & 1.26 & 103 & 4.95 & 1.31 & & & & & & $-3.90 * * *$ \\
\hline & Spread & 281 & 0.54 & 0.76 & 95 & 0.04 & 0.34 & & & & & & $6.21^{* * *}$ \\
\hline & Log maturity & 312 & 2.56 & 0.61 & 99 & 2.63 & 0.57 & & & & & & -1.02 \\
\hline & Guarantee & 338 & 0.33 & 0.47 & 103 & 0.13 & 0.33 & & & & & & $4.11 * * *$ \\
\hline & Loan revision & 338 & 0.11 & 0.32 & 103 & 0.06 & 0.24 & & & & & & 1.61 \\
\hline \multirow{4}{*}{$\begin{array}{l}\text { Counter- } \\
\text { party firm }\end{array}$} & Intra-group loan & 338 & 0.62 & 0.49 & 103 & 0.85 & 0.35 & & & & & & $-4.52 * * *$ \\
\hline & Counter-party industry & 308 & 0.42 & 0.49 & 96 & 0.41 & 0.49 & & & & & & 0.27 \\
\hline & Counter-party size & 261 & 1.81 & 1.77 & 68 & 4.73 & 2.10 & & & & & & $-11.64 * * *$ \\
\hline & State-owned counter-party & 332 & 0.55 & 0.50 & 103 & 0.67 & 0.47 & & & & & & $-2.08 * *$ \\
\hline \multirow{8}{*}{$\begin{array}{l}\text { (Loan- } \\
\text { announcing) } \\
\text { Firm }\end{array}$} & Firm size & 337 & 22.12 & 1.11 & 103 & 21.86 & 1.39 & 11,738 & 21.46 & 1.45 & $8.28^{* * *}$ & $2.78^{* * * *}$ & $1.98^{* *}$ \\
\hline & Age & 337 & 10.95 & 4.71 & 103 & 11.34 & 5.09 & 10,926 & 9.61 & 5.16 & $4.71 * * *$ & $3.39 * * *$ & -0.71 \\
\hline & Market to book ratio & 333 & 2.14 & 1.22 & 102 & 2.29 & 1.59 & 11,461 & 2.32 & 1.58 & $-2.01 * *$ & -0.18 & -1.02 \\
\hline & Free cash flow & 319 & 0.02 & 0.17 & 97 & 0.03 & 0.14 & 10,441 & 0.04 & 0.15 & $-2.29 * *$ & -0.74 & -0.94 \\
\hline & Leverage & 337 & 0.47 & 0.19 & 103 & 0.61 & 0.22 & 11,738 & 0.50 & 0.24 & $-2.69^{* * *}$ & $4.81^{* * *}$ & $-6.64 * * *$ \\
\hline & State control & 337 & 0.71 & 0.45 & 103 & 0.67 & 0.47 & 11,050 & 0.51 & 0.50 & $7.24 * * *$ & $3.24 * * *$ & 0.76 \\
\hline & Other accounts receivable & 337 & 0.03 & 0.04 & 103 & 0.02 & 0.03 & 11,580 & 0.04 & 0.06 & $-2.80^{* * *}$ & $-2.16 * *$ & 0.82 \\
\hline & Other accounts payable & 337 & 0.04 & 0.04 & 103 & 0.08 & 0.10 & 11,585 & 0.05 & 0.07 & $-4.07 * * *$ & $3.84 * * *$ & $-6.21 * * *$ \\
\hline
\end{tabular}

